일본 원폭피폭자원호의 제도화와 새로운 자격의 범주로서 '피폭자'의 의미 구성* **

\title{
오은정
}

\section{1. 머리말}

한국의 국립국어원 표준국어대사전에는 등록되지 않은 단어지만, 일본에서 히바쿠샤(被爆者), 곧 ‘피폭자’라는 말은 그리 낯선 용어가 아니다. 사전적 의 미로는 '원자폭탄 혹은 그 방사선에 노출된 사람'을 뜻하고, 실제로는 1945년 히로시마와 나가사키에 떨어진 원자폭탄의 폭격에서 살아남은 이들을 가리

오은정(吳殷政) 현재 한림대학교 일본학연구소 HK연구교수. 서울대학교 화학과 학사, 동 대학 환경대학 원 석사, 동 대학 인류학과에서 박사학위를 받았다. 한국원폭피해자의 역사, 일본 원폭피폭자원호정책의 자장(磁場) 속에서 작동하는 과학, 정치, 관료제의 측면에 대해 관심을 가지고 연구했다. 주요 논문은 「관 료제적 문서주의 속에서 기록과 기억: 한국 원폭피해자의 일본 피폭자건강수첩 취득 과정에 대한 민족지 적 연구」(『한국문화인류학』, 2014), "Nationalism and Reflexive Cosmopolitanism in Korean A-bomb Victims’ War Memory and Transnational Solidarity”(Development and Society, 2017) 등이 있다.

* 이 글에는 필자의 박사학위 논문의 일부가 포함되어 있으며, 본고의 중요 내용은 2017년 11월 14 일 서울대 일본연구소에서 개최한 전문가 세미나에서 “일본 원폭피폭자 원호정책의 전개와 '피폭'의 경계' 로 발표한 바 있다. 세미나에서 중요한 질문과 지적을 해주신 서울대 일본연구소 선생님들께 감사의 말 씀을 드리며, 익명의 심사자 여러분들의 논평에도 감사드린다.

** 이 논문은 2017년도 정부(교육부)의 재원으로 한국연구재단의 지원을 받아 한림대학교 일본학연구 소가 수행하는 인문한국플러스지원사업의 일환으로 이루어진 연구임(2017S1A6A3A01079517). 
키는데 사용된다. 2011년 3월 11일 일본 동북지방을 덮친 쓰나미로 후쿠시 마원전 사고가 일어난 이후 다시 피폭이 이슈가 되었지만, 현재 이들은 피 난자(避難者)나 피재자(被災者)로 불리는 경우가 더 많다. 원전 사고 이후 누 출된 방사능에 피폭된 이들을 가리킬 필요가 있을 때는 특별히 ‘被曝者’나 ‘被ばく者’로 표기하기도 한다.

일본에서 피폭자의 존재는 표기법에 있어서만 특별한 것이 아니다. 무 엇보다 이 피폭자라는 용어는 전후 일본의 정치사회 진영에서 다양한 의미 를 내포하며 여러 실천과 활동의 표상으로 자리 잡아 왔다. ${ }^{1}$ 아주 드물게는 일본 정치 지형의 양 극단에서 핵무장론이나 반미투쟁의 근거가 되기도 하 고, 패전의 표식으로서 망각되어야 할 수치로 해석되는 경우가 있다. ${ }^{2}$ 하지 만 반전과 반핵이 중심이 된 일본의 평화운동에서 피폭자는 무엇보다 전쟁 의 비극적 상징으로서 전쟁과 핵무기의 피해자, 그리고 그 위험을 몸으로 증명하는 그들의 존재 자체로 핵무기 폐절이라는 가치를 드러내는 가장 강 력한 표상이자 실천의 주체가 되어왔다. ${ }^{3}$

일본에서 히로시마와 나가사키의 원자폭탄의 피해자들 곧 피폭자는 자 신들의 원폭 경험을 생생하게 전달해 행사의 취지를 효과적으로 설명해내 는데 있어 핵심적인 역할을 수행하며, 그 의식의 시작과 끝은 대체로 이들 의 체험을 듣는 것으로 채워진다. 피폭자의 이야기를 경청하는 것은 마치 의례와도 같아서, 그들의 증언은 행사에서 경건한 분위기를 연출해낸다. 피 폭자들을 내세운 여러 사회운동을 '재난을 파는' 혹은 '원자폭탄을 깃발로 사용하는'4 행위로 비난하는 이들이 생긴 것도 주류적 피폭자 담론에 대한 반발적 성격이 짙다. 그만큼 피폭자, 곧 히바쿠샤라는 단어가 사회적으로

1 Lisa Yoneyama, Hiroshima Traces: Time, Space, and the Dialectics of Memory, University of California Press, 1999.

2 根本雅也, 『広島の戦後三○年間にみる原爆被害の表象と実践』, 2006, 一橋大学社会学研究課修士論 文, 1空.

3 Yoneyama, Hiroshima Traces; 竹峰誠一郎, 「被爆者’という言葉がもつ政治性」『立命平和研究』9号, 2008, pp.21 23.

4 Susan Lindee, Suffering made Real: American Science and the Survivors at Hiroshima, Chicago \& London: The University of Chicago Press, 1994, p.5. 
활발하게 유통된다.

원수폭금지세계대회가 시작된 1954년 이후부터 히로시마와 나가사키 의 원폭 참사에 대한 피폭자들의 증언은 이 공적인 정치회합의 공식적인 설 명으로 대중들에게 연설·전달됐다. ${ }^{5}$ 신형 대량살상 무기의 끔찍함과 공포 를 알리는 것으로 그들의 체험은 반핵 운동을 촉진시키는데 중요한 도구였 다. 일본의 반전, 반핵 그리고 평화운동의 ‘진정성의 핵'6과 같은 존재로서 피폭자 그리고 그들의 원폭체험이 핵 혹은 방사능의 피해와 관련해서는 그 사용빈도가 매우 높을 뿐만 아니라 반핵운동이나 평화교육과 평화연구 등 의 분야에서도 매우 적극적으로 활용되는 이유다. ${ }^{7}$

그렇다면 히로시마와 나가사키의 원폭으로 인해 피해를 입은 사람들을 피폭자라고 부르는 것은 당연한 일일까. 이 글은 일본에서, 좀 더 구체적으 로는 일본의 원폭피폭자원호정책에서 규정된 '히바쿠샤', 즉 '피폭자'라는 용어가 오히려 일본의 피폭자원호정책 상의 법과 행정적 측면에서 구성된 개념으로서, 제도적 측면에서 그 경계가 중층적으로 형성되고 변화되어온 측면에서 포섭한 것, 그리고 동시에 배제한 것들을 주목해야 하는 점에서 출발한다.

본문의 구성은 크게 세 개로 나누어지며, 2절에서는 히로시마와 나가

5 竹峰誠一郎,「“被爆者’という言葉がもつ政治性」, 21驽.

6 Lindee, Suffering made Real, p.5.

7 권혁태, 「히로시마/나가사키의 기억과 '유일피폭국’의 언설」, 『일본비평』 제 1 호, 2009, 그린비, 60 89 쪽; 박경섭, 「조선인원폭피해자와 초국적 시민(권)」, 『현대사회과학연구』제13권, 2009, 153 166쪽. 일본의 유일피폭국 언설과 피폭자 중심의 평화 담론들, 히로시마와 나가사키의 원폭피해에 대한 시공 간적 재현 그리고 그 속에서 한국원폭피해자들의 위치를 조명한 연구들이 있다. 이들 연구들에서 한 국원폭피해자는 유일피폭국과 평화 담론 속에 가려졌지만, 그것의 모순을 드러내는 역사적 존재로서 부각된다. 연구자는 이들 연구의 주장에 동의하지만, 한편으로는 '유일피폭국'이라는 표상이 일본의 중앙 정부보다는 히로시마와 나가사키 시(市) - 현(県) 등과 같은 지방 정부나 일본피폭자운동 단체 등을 중심으로 강하게 채택되는 경향이 있다. 중앙 정부가 그 용어를 사용하는 맥락도 지방 정부나 피 폭자운동단체들과는 차이가 있다는 것에 크게 주의를 기울이지 않는다는 점을 지적하고 싶다. 가령 일본 중앙 정부가 채택하는 유일피폭국의 표상이 전후 국가 보상 범위가 어디까지인가는 매우 까다롭 고 미묘한 상황에서 채택된 국내 정치용이라는 점은 일본의 원폭피해자구호정책의 장에서 잘 드러난 다. 일본 중앙 정부는 유일피폭국이라는 표어를 채택하면서도 그 언설에 부합되는 법적 조치들은 언 제나 '다른 일반 전쟁의 피해자들과의 균형'을 고려하는 속에서 최소한에 머물렀다. 즉 유일피폭국의 언설은 일본의 중앙 정부보다는 히로시마와 나가사키, 그리고 반핵 단체들 사이에서 더 열렬하고 진 지하게, 그리고 중앙 정부를 압박하는 과정에서 사용하는 측면이 강하다. 
사키의 원폭으로 인해 영향을 받은 사람들을 부르는 다양한 용어들의 어사 (語史)적 측면 변화를 통해 정치사회적 의미가 함축하는 바를 살펴본다. 3절 에서는 패전 직후 일본에서 전재민구호라는 측면에서 이른바 '일반의 전재 민(戰災民)'과 구분되지는 않았지만, 피폭의 인체 영향의 과학연구 측면에서 비상한 관심의 대상이었던 '원폭생존자'에 대한 미·일 공동의 인체 영향 연 구 진행을 살펴본다. 4절에서는 비키니 피재를 계기로 '피폭'에 대한 일본 사회의 관심이 급격하게 증가하면서, 기존의 '원폭장해자' 구호 운동이 '원 폭피폭자의료에관한법’으로 제도화된 과정을 살펴본다. 마지막 결론에서는 히로시마와 나가사키의 원폭 투하로 인해 영향을 받은 이들이 ‘전재민’에서 ‘원폭피폭자’로 전환되고, 피폭자의 경계가 행정관료제적으로 한정되는 과 정이 생물학적 측면에서 피해에 대한 구호로 '일반의 전재민'들과 구분되어 특수하게 의미화되는 맥락을 기술한다. 그리고 이것이 과거 제국 일본의 전 쟁 책임을 부정하면서 소거해가는 과정임을 밝힌다.

\section{2. 이름 짓기의 정치}

히로시마와 나가사키의 원폭으로 인해 피해를 입은 사람들을 피폭자, 즉 히 바쿠샤라고 부르는 것은 당연한 것인가. 비교를 위해 영어와 한국어 표현을 살펴보는 것도 좋을 듯하다. 우선 영어에서 이들을 지칭하는 가장 일반적인 표현은 히로시마와 나가사키의 원폭생존자(atomic bomb survivors in Hiroshima and Nagasaki)다. 영어식 표현에서 원자폭탄피해자(Atomic-bomb victim)라는 용 어가 있어 좀 더 피해를 강조하는 경우가 있지만, 생존자라는 표현이 보다 일반적으로 사용된다. 연구자가 본 논문에서 인용하고 있는 원폭피해자 관 련 저작들 중 영어권 독자를 대상으로 하고 있는 주요 영문 서적의 저자들 이 모두 원폭생존자라는 용어를 사용한다. ${ }^{8}$ 
히로시마와 나가사키에 원폭이 투하된 이후 군사적이나 과학적 이유로 그곳에서 죽지 않은 사람들, 즉 '생존자'에 대한 관심은 매우 컸다. 아시아. 태평양전쟁 종전 후 일본에 주둔한 연합군사령부는 미국의 군부와 학계 의 의견에 따라 원자폭탄에 의한 인체 영향을 연구하기 위해 1946년 원폭 상해조사위원회 $(\mathrm{ABCC})^{9}$ 를 설치하고, 여기에서 줄곧 원자폭탄을 맞았으나 '살아 있는 사람들'과 이들의 이후 상해 및 사망에 이르는 경로 등을 추적 했다. 1954년부터 1957년까지 ABCC 위원장을 지냈던 로버트 홈즈(Robert Homes)는 이들을 '현존하는 가장 중요한 사람들' 그리고 '인류 역사에서 매 우 중요한 역할을 수행할 흔치 않은 소수의 사람들'이라고 말했다..$^{10}$

이후 이 '매우 희귀하고 귀중한 지적 자원'11으로서 '원폭생존자'들은 미국과 일본을 비롯한 여러 나라의 연구진에게 포괄적인 과학 연구의 대 상이 됐다. $\mathrm{ABCC}$ 를 비롯한 연구기관에서 나오는 논문이나 보고서에서는 주로 이들이 방사선을 쪼인 사람이라는 것을 강조하기 위해 "방사선 혹은 원 폭에) 노출된 사람'(exposed one/exposure)으로 부르거나 노출된 방사능의 수 준에 따라 분류해 지칭할 수도 있다. 예를 들어 'person who have received radiation dosages about 50 rads' 혹은 'person who have been exposed to level about $100{ }^{\prime}$ 등으로 풀어 쓰는 식이다. ${ }^{12}$ 하지만 이런 경우는 일반적이 지 않으며, 오히려 일본어 히바쿠샤와 대응되는 단일한 용어 없이, 단어 그 대로 hibakusya 혹은 hibakusha로 음차하고 위와 같은 설명을 붙이는 것이 일반적이다.

한국에서는 원폭피해자라는 용어를 좀 더 널리 쓰지만, 피폭자라는 용 어도 사용하고 있다. 그러나 두 용어 모두 하나의 단어로 국립국어원 표준

작들이 '원폭생존자' (atomic bomb survivors)를 사용하고 있다.

9 Atomic Bomb Casualty Commission, $\mathrm{ABCC}$ 로 약칭. 이 기관은 현 방사선영향연구소(Radiation Effects Research Foundation, RERF)의 전신이다.

10 Lindee, Suffering made Real, p.2 3.

11 Lindee, Suffering made Real, p.4.

12 Ahores A. Medvedev, The legacy of Chernobyl, New York: W. W. Norton, 1990, p.136. 
어사전에는 등록되어 있지 않다. ${ }^{13}$ 1945년 12 월 복간한 『동아일보』를 중심 으로, 1946년 10월 1일에 창간한『경향신문』, 이후『매일경제』까지 총 세 개의 신문과 검색 결과를 제공하는 디지털아카이브 검색결과에서도 '원자 탄 피해'와 관련된 내용 중 한국전쟁 이전 시기는 거의 나오지 않는다. 미국 과 소련이 원자탄과 수소폭탄 개발과 관련 핵실험을 통해 경쟁적으로 핵무 기 개발에 뛰어든 상황, 그리고 한국전쟁 당시 원자탄 사용 논쟁 등에 대한 기사가 자주 다뤄진 것에 비하면 확실히 피해를 입은 사람들에 대한 기사가 거의 없었다고 할 수 있다. 실제 검색 결과에서도 '원자탄의 효능'으로서 대 량인명살상과 파괴력에 대한 언급은 있지만, 피해를 입은 사람 자체를 다룬 기사는 찾을 수 없었다. 다만 영어의 'survivors'에 해당되는 표현을 풀어쓴 것으로 보이는 '원자탄 폭발 당시의 피해를 면한 잔존자'14라는 표현이 유 일하게 나오는데, 그 수가 광도(広島, 히로시마)에서만 몇 만에 이른다는 내용 에서 다뤄지고 있다.

1950년대 이후에는 '생존자'15 혹은 '광도의 주민'16 등과 같은 표현이 나오기 시작하는데, 특히 1954년 미국의 태평양 비키니 섬에서의 수폭 실 험 이후 '원폭환자', '원자폭탄의 피해자', '원폭피해자’라는 표현이 본격적 으로 상용되기 시작한다. ${ }^{17}$ 이는 '원자폭탄피해자’라는 용어가 일본에서 대 중적으로 사용되기 시작한 시기와 같다. 그리고 이후 1960년대 한일회담을 즈음하여 피폭자(被爆者)라는 한자 용어가 등장하기 시작해, ${ }^{18}$ 이후 원자폭 탄 피해와 관련된 일본 정부 및 시민단체, 연구기관과의 교류 등을 소개하 는 기사에서 간간히 이 표현이 사용되고 있음을 알 수 있다. 이 시기는 일본 에서도 피폭자, 즉 히바쿠샤라는 용어가 사용되던 때였다.

그러나 피폭자라는 한자 용어가 신문지상에서 일반적으로 사용되었지

13 국립국어원 표준어대사전 「피폭자」검색(http://stdweb2.korean.go.kr/ 최종검색일: 2018. 6. 14).

14 『동아일보』, 1947. 5.31.

15 『경향신문』, 1952.7.27.

16 『경향신문』, 1952, 4. 25.

17 『동아일보』, 1954. 9. 20.

18 『동아일보』, 1963. 8.6. 
만, 방사능에 노출된 사람이라는 의미로 더 쓰였을 뿐 원자폭탄의 피해자라 는 의미로 사용되는 경우는 많지 않았다. 1968년 설립된 한국의 원자폭탄 피 해자 단체인 한국원폭피해자협회[(구) 한국원폭피해자원호협회]는 여전히 '원폭 피해자'라는 용어를 사용했으며, 현재도 마찬가지다. 이처럼 한국에서는 '피 폭자'라는 용어가 사용되지만, 일반적으로 원폭피해자라는 용어가 더 널리 쓰임을 알 수 있다. 반면 일본에서는 원폭피해자의 일본어 표현인 '겐바쿠히 가이샤'라는 용어는 특수한 맥락을 가질 때를 제외하고 잘 사용하지 않는다.

히로시마와 나가사키에 투하된 원자폭탄으로 인해 직·간접적인 영향을 받은 이들을 지칭하는 용어들이 모두 완전히 일치되는 기준과 범주를 가지 고 있지 않은 것은 당연하다. 그러나 한국인인 연구자가 당연하게 원폭피해 자라고 불러오던 그들을 영어로는 원폭생존자, 일본에서는 히바쿠샤로 부 르는 것이 더 자연스러운 일로 여겨지는 것은 원폭 투하와 관련된 정치적 책임과 비난을 자연스럽게 담아내고 있다. 이 용어들의 이름 짓기는 정치 속에 내재하는 책임 소재의 방향을 짐작게 한다.

그렇다면 일본에서는 언제부터 피폭자라는 용어가 히로시마와 나가사 키의 원폭피해자들을 가리키는 일반적인 표현으로 자리 잡게 되었을까? 이 용어는 그들의 존재가 생겨난 직후 곧바로 일반적으로 사용되어 왔던 것일 까? 일본에서 피폭자라는 용어의 어사(語史)를 추적한 바 있는 다케미네의 연구를 인용해본다. ${ }^{19}$ 다케미네에 따르면 일본에서도 피폭자라는 단어가 전후 10 년 동안에는 사용되지 않았다고 보고하고 있다. 그 예로 일본의 대 표적인 국어사전인 『大言海』(1956년 개정판)와『広辞苑』(1955년 초판)에도 피 폭(被爆)이나 피폭자라는 단어는 게재되지 않았다. 두 사전 모두 원폭투하 후 10 년이 지나 개정되거나 초판으로 나온 사전들이었다.

그는 언론 매체들도 사정은 마찬가지였던 것으로 기록하고 있다. 1952년 8월 6일을 맞아 잡지 『아사히그라프』(アサヒグラフ)가 '원폭피해의 최초공개' 라는 제목으로 발행한 특별호는 원폭 당시의 사진을 게재한 첫 출판물이라

19 竹峰誠一郎, 「“被爆者”という言葉がもつ政治性」, 21 23胥. 
할만한 것이었음에도 피폭자라는 단어를 사용하지 않았다. 다만 이곳에는 피폭이라는 단어가 군데군데 쓰였다. 대신 당시 원자폭탄으로 재난을 당한 사람들을 가리켜 원폭희생자(原爆犧牲者), 부상자(負傷者), 중상자(重傷者), 화 상자(火傷者), 폭사자(爆死者), 원폭생존자(原爆生存者), 원폭의 아이(原爆の子), 원폭처녀(原爆處女) 등의 용어를 사용했다. 『아사히신문』(朝日新聞) 표제에서 도 마찬가지로 1945년부터 5년간 원폭피재자, 원폭희생자, 원폭고아(原爆孤 兒), 원폭을녀(原爆乙女), 원폭장해자(原爆障害者)와 같은 용어가 사용되었으나 피폭자라는 단어는 사용되지 않았다. 이 단어가 처음 나타난 것은 원폭투하 로부터 10년이 지난 1955년 8월이었다. 즉 일본의 국어사전이나 매체들에 서도 피폭자라는 단어는 원폭투하 이후 약 10 여 년간 사람들 사이에서 일 반적으로 통용되는 단어는 아니었다고 볼 수 있다.

이 같은 양상은 피폭자가 중심이 된 사회운동에 있어서도 마찬가지였 다. 1955년 열린 최초의 원수폭금지세계대회에서도, 그리고 그 후 결성된 원폭생존자들의 단체인 히로시마현원폭피해자단체협의회(히로시마피단협, 1956년 5월 결성)와 나가사키원폭피재자협의회(나가사키피재협, 1956년 6월 결성), 그 위의 전국 조직인 일본원수폭피해자단체협의회(일본피단협, 1956년 8월 결성) 의 발족에서도 피폭자라는 단어가 아닌 원폭피해자와 원폭피재자라는 용 어가 사용됐다. 현재 이들 단체는 모두 원폭피해자, 원폭피재자라는 용어를 원폭피폭자라는 용어로 대체했다. ${ }^{20}$

한편 $\mathrm{GHQ}$ 의 점령이 해제되고 전후 처리 문제가 일본 사회의 주요한 정치적 의제로 떠올랐던 1951년 즈음, 히로시마 시는 원폭으로 인해 희생 된 시민들에 대한 국가 보상 대책을 대비해 관련한 실태조사를 벌인 적이 있다. 당시 그 공식 명칭은 '히로시마시원폭장해자조사'였다. ${ }^{21}$ 또한 일본 내 원폭피해자 원호법 제정 운동이 고양되던 1956년 무렵에 히로시마 현과 히로시마 시, 나가사키 현과 나가사키 시당국이 지역민들의 희망을 담아 원

20 広島県原爆被爆者団体協議會, 『核兵器のない明日願をって: 広島被団協の歩み』, 2001.

21 広島県, 『被爆40年原爆被爆援護のあゆみ』, 広島県, 1986, 37叒. 
호법안을 작성하고 관련된 진정서를 정부와 국회, 각 정당 등에 제출했을 때에도 그 명칭은 여전히 '원폭장해자원호법안요강'이었다.22

이처럼 원폭 전후 십여 년간 히바쿠샤, 즉 피폭자라는 용어는 사회운동 진영이나 피해자 단체 심지어 지방행정당국에서도 일반적으로 사용하지 않 았었다. 오늘날 피폭자로 불리는 이들은 애초에 '전재민', '피재자', '부상자' 등과 같이 전후 일본의 여러 전쟁피해자들과 마찬가지로 지칭되었다. 그리 고 이후 점차 그 피해의 근원이 원폭으로 초점이 맞춰지면서 원폭생존자나 원폭피해자, 원폭희생자, 원폭장해자, 원폭을녀, 원폭처녀, 원폭고아 등과 같은 다양한 용어들로 차별화되었다.

피폭자라는 용어가 원자폭탄의 방사선이라는 특수한 측면과 결합해 만 들어지고, 그 배경에는 일본 정부의 전후보상과 정부 예산의 문제가 결합되 어 있다고 지적한 다케미네는, 피폭자라는 용어의 부상(浮上)의 배경을 일본 의 원폭의료법(원자폭탄피폭자의의료등에관한법률, 1957)의 역사적 맥락에서 살펴 보아야 한다고 지적한다. 그는 일본의 법률상 피폭자라는 것은 일본 정부가 히로시마와 나가사키의 원폭피해자 가운데 원호대상으로 인정한 사람을 총 칭하는 단어로서, 이는 특히 원자폭탄의 '방사선'과 '건강면'의 영향에 한정 된 것이며 한편으로는 행정적 통달 조치를 통해 국내적으로 원호 대상을 한 정하기 위해 조작되어온 측면을 가지는 극히 정치적인 단어라고 비판한다.23

요네야마 또한 일본사회에서 원폭생존자를 피폭자라는 일면적 측면을 부각해서 지칭해 규정하는 것과 관련된 담론적 질서를 설명하면서, 이 용 어의 법제도적 기원을 설명한 적이 있다. ${ }^{4}$ 그는 일본 정부가 원폭의료법과 원폭특별조치법을 제정해 원폭생존자들에게 의료 혜택을 주게 되었는데 이 러한 공식적인 피폭자 인증 절차가 전후(戰後)의 반핵담론과 결합해 일본 사 회의 주류적인 피폭자 담론을 만들어냈다고 이야기한다. 피폭자 인증 제도 절차와 관련된 의학적, 법적 담론들이 그들의 설명에 진실성이라는 권위를

22 広島県, 『被爆40年原爆被爆援護のあゆみ』, 40䂬.

23 竹峰誠一郎,「“被爆者”という言葉がもつ政治性」, 21 23空.

24 Yoneyama, Hiroshima Traces, 92 96胥. 
부여했고, 반핵운동은 원폭생존자들을 피폭자라는 하나의 정치적 의제로 결합한 강력한 의지와 열망을 가진 정치 주체로 내세웠다는 것이다.

이어서 요네야마는 이 같은 제도적, 사회 운동적 차원의 담론 결합은 피 폭자라는 단어가 강력한 정치적 영향력을 행사하는 표상이 된 만큼 그것이 의료화·제도화된 국가 담론 속에서 결코 자유롭지 못하게 된 측면을 만들 어냈다고 보았다. 그는 이것이 피폭자라는 것으로 이야기되고 그 안에서 만 들어진 주체는 다층적이고 모순적인 모습들이 아니라 '방사선에 노출된 사 람'이라는 일면적인 차원에 한정되어 원폭 생존자들을 규정하고 있기 때문 이라고 주장했다. 또한 원자폭탄 경험은 한 사람의 인생 경로의 한 과정일 뿐, 주류 매체나 주류 담론에서 피폭자라는 단어로 그 사람을 규정함으로써 이들에게 단일한 형태로 맞추어진 경험을 특정 방식의 서사 스타일에 따라 서 이야기하게 한다. 또한 그들이 살아온 중첩된 관계와 상호작용 속에 다 층적인 요소들에 대한 언급을 자제시키는 것이 그 효과다.

실제로 히로시마와 나가사키의 원폭을 경험하거나 그와 관련된 사람들 의 이름을 짓는데 있어 피폭자라는 표현이 갖는 의미 축소를 비난하는 것 은 일본의 운동 진영에서는 그리 낮선 것도 아니었다. 히로시마에서 원폭피 해자상담원 모임의 학습회를 운영했던 구루스 다케시로(來栖武士郎)는 이 단 체명에 다른 단체들과 달리 '피폭자' 즉 '히바쿠샤'라고 하지 않고 원폭피해 자라는 용어를 썼다. "피폭자수첩을 소지하고 있는, 이른바 공인의 피폭자 뿐만이 아니라 피폭자지만 아직 수첩을 가지고 있지 않거나 가족을 원폭으 로 잃은 피폭당하지 않은 유족이나 고아 등의 관계자를 포함해 원폭에 의한 피해자 모임 활동을 대상으로 하고자 하는 뜻이었다. 원폭2법 25 으로 규정된 피폭자뿐만 아니라 원폭에 의해 피해를 입은 사람들 모두를 상담- 원조의 대상으로 하는 것으로, 원폭2법의 한계를 넘어서 그 개정을 시야에 두고 활

25 1957년에 제정된 『원자폭탄피폭자의의료등에관한법률』(원폭의료법), 이어서 1968년 『원자폭탄피폭 자에대한특별조치에관한법률』(특별조치법)을 합해 원폭2법이라고 부른다. 이 두 개의 법률은 1994 년 『원자폭탄피폭자에 대한 원호에 관한 법률』(원폭원호법)이 제정될 때까지 일본의 원폭피해자 의 료급부 지원의 법적 근거였다. 이 세 법을 원폭3법이라고도 표기한다. 
동을 추진하려고 하는 결의의 표명에 다름 아니다”라는 것이었다. ${ }^{26}$

그렇다면 왜 하필 '방사능만의 피해'였을까? 앞서 인용문에서 여러 연 구자들이 지적한 것처럼 피폭자라는 용어는 분명히 지나치게 일면적인 차 원으로 규정된 용어임이 분명하다. 원자폭탄은 개인의 신체나 심리, 사회적 관계 및 공동체 수준 등 매우 다양한 수준에서 피해를 초래하고, 원자폭탄 자체가 방사능뿐만 아니라 폭발과 열기, 바람, 화재 등 원인도 다양하며, 피 폭을 직접 당한 사람뿐만 아니라 그들 가족들의 삶에도 복잡한 영향을 미쳤 다는 것을 모두 포함하지 않는 표현임이 분명하다. 그런데 왜 하필이면 방 사능의 피해만은 인정했을까? 그리고 왜 매우 일면적인 것에만 집중하게 됐을까? 이는 역으로 다른 피해들은 왜 구호의 대상이 될 수 없는지를 묻는 것이기도 하다. 이와 관련해서 앞서 지적한 바와 같이 법적으로 특정한 대 상을 지칭하고 명명하는 것이 단순히 이름을 짓는 것 이상으로 특정한 책임 과 비난의 소재까지 다루고 있다는 것을 염두에 둘 수 있을 것이다. 특히 이 것은 제국 일본의 전쟁 책임 인정 및 패전 후 일본의 전후 전쟁 보상 문제와 깊은 관련을 맺고 있다. 다음 장에서는 일본의 원폭피해자 구호 정책 자체 의 탄생이 특수한 역사적 구성의 산물임을 제시하면서 원폭에 의한 인체 영 향 연구가 구호 문제보다 훨씬 더 일찍 일본 정부와 미국 정부의 관심 대상 이었음을 보이고자 한다.

\section{3. 연합군 점령하의 원폭생존자 연구와 구호의 경과}

\section{1) 연합군 점령하의 원폭생존자 연구}

패전 후 연합군사령부의 점령 하에서 일본의 원폭피해자들은 다른 전쟁피 해자들인 소위 전재자(戰災者)와 차별화되지 않았다. 전시구호와 전재부흥 의 관점에서는 이때까지도 히로시마와 나가사키의 전재민들은 다른 모든 

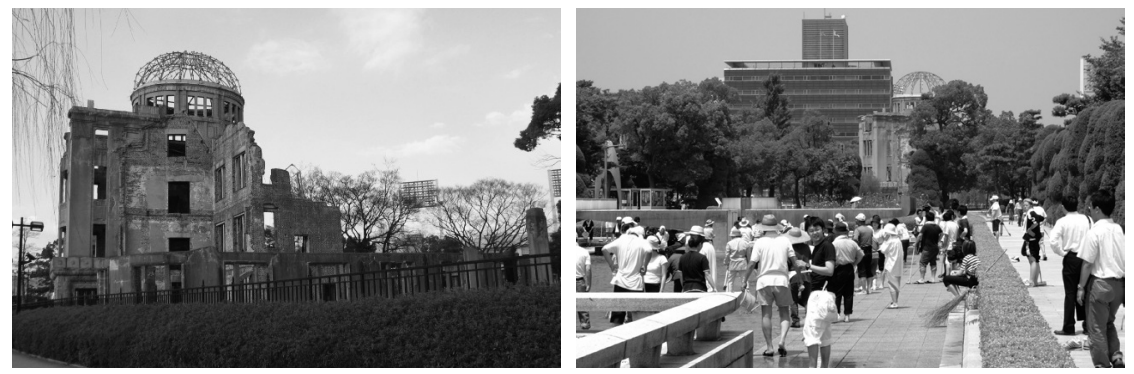

히로시마 원폭돔(좌측)과 매해 8월 6일 열리는 평화기념식전 준비를 위해 히로시마평화공원에 모여 청소를 하는 시민들(우측). 필자 촬영.

전쟁피해자들과 마찬가지로 연합군 공습의 피해자 범주에 뭉뚱그려져 있었 다. 전재민들의 구호를 예로 들어보자면, 종전 직후 연합군의 공습으로 인 해 죽거나 다친 사람들은 전시재해보호법에 따라 구급구호를 받았는데, 히 로시마와 나가사키에서 공습의 피해를 입은 부상자들도 이 법에 따라 설치 된 임시구호소들에서 치료를 받았다. ${ }^{27}$

피해 규모가 심대하고 특별했지만 동법의 규정에 따라 재해 후 60 일인 1945년 10월 5일과 9일을 기해 구호소가 폐쇄되면서 이후의 구호는 개인 들의 몫이 됐다. 같은 해 12 월에 히로시마의 전재자들이 모여 히로시마전 재자동맹대회를 개최해 구호를 호소했으며, 곧이어 이듬해 1 월에는 전쟁으 로 인해 부모를 잃은 아이들의 수용을 위한 히로시마전재고아육성소가 개 소되기도 했으나 이들을 위한 특별한 구호 활동은 여전히 진행되지 않았다. 공습 1년을 맞는 1946년 8월 6일 히로시마에서는 이 날을 기념하는 소박한 행사가 열렸는데, 그것은 히로시마 시와 히로시마시전재사몰자공양회가 공 동주최한 전재사몰자 1 주년추도법회였다. ${ }^{28}$

전재민 중에서도 특히 히로시마와 나가사키의 시민들이 문제가 된 것 은 의료적, 정책적 측면보다는 군사 및 과학적 관점에서였다. 연합군의 공 습 직후 히로시마와 나가사키에 떨어진 신형무기가 종래의 무기와는 차원

27 広島県原爆被爆者団体協議會, 『核兵器のない明日願をって: 広島被団協の歩み』, 361空.

28 広島県原爆被爆者団体協議會, 『核兵器のない明日願をって: 広島被団協の歩み』, 361票. 
이 다르며, 원자폭탄일 가능성을 염두에 두고 가장 처음으로 조사를 벌인 곳은 일본 군부였다. ${ }^{29}$ 일본군부와 정부당국은 신형무기 공격에 관한 정보 를 수집하고 전쟁을 지속할 것인가의 여부를 두고 대책을 세울 필요가 있었 다. 때문에 과학적 조사를 동반해야할 이 군사적 관심은 공습 직후 다른 어 떤 것보다 시급하고 즉각적인 조치로 이어졌다.

대본영은 8 월 8 일, 히로시마 시에 대본영조사단을 파견했다. 대본영조 사단은 8 월 10 일 조사를 정리하면서 이것이 '원자폭탄'이라고 결론 내렸다. 보고서에는 폭탄의 영향이 극히 심대하며 특히 방사선에 의한 영향으로 추 정되는 피해 즉 백혈구가 감소한 자, 외상은 없었으나 폭격 후 1 2일 내 갑 자기 사망하는 자 등이 상당하고 원폭 투하 이후에도 중심부근의 토사에서 계속 방사선이 검출되고 있다는 기록이 담겼다. ${ }^{30}$ 대본영조사단의 초동수 사와 함께 육군성 의무국 소속 히로시마재해조사반의 조사활동도 이뤼졌 다. 이 조사반은 군의들로 구성된 것으로 군사전략적 판단을 위한 대본영조 사단의 것보다는 일반 시민의 심각한 피해에 대한 조사가 일차적 목적이었 다. 이들은 원자폭탄의 인체에 대한 효과와 피해의 조사, 신병기의 전상(戰 傷)의 연구와 치료방침을 수립할 목적으로 이 연구를 수행했다. ${ }^{31}$

군부의 즉각적인 조치는 학계와도 연결됐다. ${ }^{32}$ 일본 군부는 자체 초동 수사를 지시함과 동시에 학계에 즉각 도움을 요청했다. 육군인 도쿄사단사 령부가 8월 6일 도쿄제국대학에 히로시마 조사를 요청하고 해군에서는 8월 7일 히로시마 시에 해군성이 해군히로시마조사단을 파견함과 동시에 오사 카제국대학에도 히로시마 조사를 요청, 오사카제국대학조사단이 8월 9일 히로시마 시에 파견됐다. 구레(吳)진수부도 원폭공격 직후부터 히로시마 시 에 조사단을 파견했다. 나가사키에서는 8 월 10 일에 나가사키지구헌병대, 8 월 14 일에 구레진수부조사단이 조사에 들어갔다. 8월 13일, 서부군에서 요

29 笹本征男, 『米軍占領下の原爆調査: 原爆被害国になった日本』, 新幹社, 1995, 17 18至.

30 笹本征男, 『米軍占領下の原爆調査: 原爆被害国になった日本』, 18䂬.

31 笹本征男, 『米軍占領下の原爆調查: 原爆被害国になった日本』, 19丝.

32 나카야마 시게루·요시오카 히토시 편저, 박영일·정경택 옮김, 『일본과학기술의 사회사: 종전에서 1980년대까지』, 한일미디어, 2000, 21 34쪽. 
청된 규슈제국대학도 조사에 참가했다. ${ }^{33}$ 일본 정부의 조사에서는 원폭투 하 직후에 내각을 기반으로 설치된 임시원폭대책위원회가 히로시마 시에 기술원조사단을 파견했다. ${ }^{34}$ 이처럼 초기 히로시마와 나가사키의 전재민에 대한 구호에 있어 일본 정부의 관심은 다른 도시들의 전재민들에 대한 그것 과 아무런 차이가 없었지만, 신형무기 원자폭탄의 위력을 보여주는 것으로 서 그 도시와 시민들에 대한 군부와 학계의 관심은 지대했다.

원폭의 인체 효과(영향)에 대한 이 두 국가의 공통된 관심사는 패전을 공 식화하고 한 달이 지난 1945년 9월 14일 일본학술회의(The Science Research Council of Japan, JSC)가 처음으로 다수의 과학자들을 동원하여, 원폭투하 후 의 상황에 대한 포괄적인 연구를 시작하는 것에 반영됐다. 이 위원회는 의 학적 효과뿐만 아니라 건물 손상, 열 손상, 대기효과, 식물 및 야생동물에 대한 효과 등에 대해서도 연구했다. 이 가운데 의학 분야는 쓰즈키 마사오 (都築正男) $)^{35}$ 도쿄대 교수가 담당자가 되었고, 그는 이후 일본과 미국 두 나 라의 방사선 인체 영향 연구에 중요한 역할을 담당하게 된다. 또한 이 계획 하에 150 명의 연구자들과 천여 명의 보조 인력이 히로시마와 나가사키에 파견된다. ${ }^{36}$ 그리고 9 월 하순에는 미국의 육군과 해군 그리고 원자폭탄을 개발한 과학그룹인 맨해튼프로젝트 팀이 일본 연구진과 별도로 히로시마와 나가사키 현지를 방문해 원자폭탄의 영향을 조사해나가기 시작했다. 연합 군의 점령 기간 동안 이루어진 히로시마와 나가사키 원폭 조사의 성격과 그 의미를 고찰하고 있는 수잔 린디(Susan Lindee)의 작업에는 당시 이 같은 미 국 정부와 군부, 일본 정부와 군부의 관심들이 잘 드러나 있다.

1945 년 10 월 12 일에 원자방사선의 피폭에 동반하는 생물학상의 급성 영향을 연구하는 미일합동조사단(US-Japan Joint Commission)이 조직됐다. 미

33 笹本征男, 『米軍占領下の原爆調査: 原爆被害国になった日本』, 19䂬.

34 笹本征男, 『米軍占領下の原爆調査: 原爆被害国になった日本』, 20 空.

35 쓰즈키 마사오(都築正男, 1983 1961)는 태평양전쟁 당시 도쿄제국대학의학부 교수면서 해군군의중 장이기도 했다. 원폭투하 직후의 미국과 일본 측의 원폭의 인체 영향 연구에 중요한 기여를 했으며, 이후에도 방사선의 생물학적 영향 연구에서 독보적인 권위를 가지고 있었다.

36 Lindee, Suffering Made Real, p.23. 
국 조사자들은 '치사에 이르는 방사선량을 흡수한 사람을 분별해서 생존가 능한 사람들에게 집중할 수 있도록 하기 위해' 방사능 피해자들을 어떻게 분류해야 할지를 파악하고 싶어 했으며, 심각한 급성방사선피폭증이 어떤 형태로 발현되는 것인지를 규명하고자 했다. ${ }^{37}$ 따라서 조사단의 관심을 실 제로 규명하기 위해서는 폭격 직후 수일에서 수주일 내에 가장 심각하게 부 상당한 생존자들의 경험에 대한 정보가 필요로 했다. ${ }^{38}$ 이 연구는 1945 년 10 월부터 한 달 동안 진행되어, 1946년 미일 공동 연구의 기초를 만드는데 중요한 데이터를 제공하게 된다. ${ }^{39}$

이후 1946년 11월, 트루먼 대통령은 히로시마, 나가사키의 생존자들에 대한 장기간의 연구를 시작하도록 하고, 이듬해 3월 미국과학아카데미는 미국원자력위원회(Atomic Energy Commission)에 기금을 얻어 원폭상해조사위 원회를 히로시마에 설립하고 곧바로 원폭에 의한 방사선의 인체 영향 및 질 병에 관한 조사연구를 실시하기로 결정한다. ${ }^{40}$ 그와 동시에 미국 측은 일본 측에 공동 조사를 제의해 1948년 3월 일본 후생성국립예방위생연구소(예연) 는 히로시마 $\mathrm{ABCC}$ 에 지소를 두고 미국 측의 연구에 협력하게 된다. 같은 해 8 월에는 나가사키에도 $\mathrm{ABCC}$ 가 설치됐다. ${ }^{41}$ 이후 방사선의 인체영향 및 유전에 관한 연구에 대한 관심, 방사능 물질을 취급하는 작업자들의 안 전 기준을 마련한다는 실질적인 목표, 그리고 당시 대중적 관심을 사로잡았 던 방사선의 유전적 영향에 대한 연구들이 개시됐다. ${ }^{42}$

개시된 연구 중 방사선 영향에 따른 유전적 문제에 대한 연구는 연구 데 이터의 신뢰성 확보와 물리적인 어려움 등이 부각되면서 폐기되지만, ${ }^{43}$ 대

37 Lindee, Suffering Made Real, p.27.

38 Lindee, Suffering Made Real, p.29 30.

39 Lindee, Suffering Made Real, p.32.

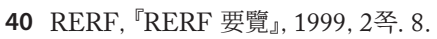

41 広島市, 『原爆被爆者対策事業概要』, 広島市, 2001, 155昰.

42 Lindee, Suffering Made Real, p.60.

43 1955년 열린 프란시스위원회에서 초기 유전연구를 비롯한 연구소의 연구 프로그램에 대한 전면적인 재검토가 이루어진 결과 연구계획이 대폭 수정되었고, 이때 초기유전연구가 폐기된다. 이 위원회의 결론이 현재 계속되고 있는 집단조사의 기초가 됐다. 
신 1950년 일본의 국세조사를 바탕으로 1955 년에 개시한 수명조사집단연 구(Life-Span Studies, LSS)가 이후 이 기관의 가장 중요한 연구 프로그램으로 정착하게 된다. 이 수명조사집단은 태내피폭자집단, 피폭자2세 집단을 대 상으로 인체의 방사선 피폭에 의한 리스크를 추적 조사할 목적으로 '추출 된’ 이들로 구성되어, 이들에 대한 역학(epidemiology), 통계, 임상, 유전학, 방 사선 생물학 연구 등을 진행하기 시작했다. 이 집단연구와 더불어 히로시마 시와 현, 나가사키 시와 현의 피폭자 종양 - 조직을 등록하도록 해 이곳에 등 록된 데이터를 수집, 해석하는 것이 또 다른 중요한 연구 분야로 떠올랐고 현재에도 여전히 진행 중이다.44

그런데 여기서 몇 가지 특징적인 것은 $\mathrm{ABCC}$ 의 활동이 원자폭탄, 특히 방사선의 인체 영향 연구를 목적으로 하는 것이었을 뿐 원폭으로 인한 부 상자들의 치료와는 전혀 무관한 것이었다는 점이다. 특히 $\mathrm{ABCC}$ 의 생존자 '무(無)치료'(No Treatment) 정책은 원폭의 실제 영향을 온전히 연구할 수 있 게 하는 것으로 피폭자를 실험용으로 이용했다는 비난을 받는 대표적인 조 치였다. $\mathrm{ABCC}$ 의 운영에서 두드러지는 또 다른 특징은 원자폭탄의 생존자 에 대한 인체 영향에 대한 연구에 대한 기금을 미국원자력위원회가 제공했 다는 점이다.

이는 일본 정부 측에서도 마찬가지로, 이 공동 연구의 기금은 일본 원 자력협력예산에서 반영됐다. $\mathrm{ABCC}$ 의 협력기관이 된 국립예방위생연구소 가 도쿄대의 전염병연구소로부터 분리 독립하면서 “원자력의 효과와 그 이 용 방법은 장래 점점 진보하는 한편 그 인체에 미치는 영향의 연구는 단순 히 일본 일개의 것이 아니라 더 넓은 인류 일반의 복지 및 공중위생의 문제 다”45라고 했다는 말은 앞으로 이 원폭생존자 연구가 ‘원자력 시대’에 필요 한 방사선의 인체 영향 연구의 기반이 될 것이라는 점을 보여준다. ${ }^{46}$ 이는

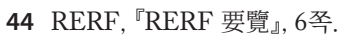

45 中島竜美, 「“朝鮮人被爆”の歴史的意味と日本の戦後責任」, 『在韓被爆者を考元る』, 在韓被爆者問題 市民会議編, 凱風社.

46 나카야마 - 요시오카, 『일본과학기술의 사회사』, 35 쪽. 
당시 원폭생존자에 대한 미일공동연구의 기반이 아이젠하워 대통령의 '원 자력의 평화적 이용' 선언과 함께 원자력 정책을 통해 핵의 정당성을 확보 해가는 과정에서 만들어졌고, 이와 관련해 방사선 장해에 대한 예방과 치료 연구를 조직적으로 실시할 필요가 있었다는 것이 일차적 목적이었다고 한 지적과도 연결된다. ${ }^{47}$

요컨대, 전후 히로시마와 나가사키의 원폭생존자에 대한 미·일공동연 구는 실험이 아닌 실제 첫 생존자 연구로서, 폭격으로 마비된 의료 및 행정 체계와 문화적 차이 속에서 어려움을 겪으며 시작됐지만 그것은 이들에 대 한 구호와는 무관한 것이었다. 대신 이 연구들은 미소냉전체제 속에서 핵무 기 사용을 염두에 둔 미국의 '시민방어계획'이라는 군사적 관심, 다른 한편 으로는 '원자력의 평화적 이용'이라는 구호와 함께 시작된 원자력(산업)시대 를 맞아 예방과 치료 수단 강구라는 차원에서 틀을 지워져 나가게 된다.

\section{2) 원폭생존자 구호의 경과}

한편, 민간 차원에서 히로시마와 나가사키의 전재민이 겪고 있는 피해의 특 수성에 주목하기 시작한 곳은 의료 분야였다. 원자폭탄으로 인한 인체의 영 향은 일반 공습으로 인한 피해와 분명히 다른 부분이 있었다. 일본의료단 히로시마 현 중앙병원은 1947 년 4월 처음으로 '원폭증'의 진료를 시작했다. 1948년 4월에는 하와이 호놀룰루에서 원폭이재민구원상담회(原爆罹災民救援 相談会)가 개최되어 히로시마현 출신자들로부터 하와이히로시마전재난민구 원회(ハワイ広島戰災民救援会) 가 결성되기도 했다. ${ }^{48}$

이 같은 민간 차원의 구호 움직임과 함께 지방 정부의 움직임도 가시화 되는 듯했다. 1949년 3월에는 처음으로 '히로시마원폭재해종합부흥대책협 의회'가 도쿄에서 개최됐다. 당시 하마이 신조(浜井信三) 히로시마 시장은 평 화기념공원과 평화기념관의 건립계획 등을 발표하고, 중앙 정부에 특별원

47 1956년 2월 13일 일본 중의원 사회노동위원회 회의록(『일본국회』http://kokkai.ndl.go.jp(2013. 4. 1. 최종접속).

48 広島県原爆被爆者団体協議會, 『原爆被爆者対策事業概要』, 362空. 
호를 요구했다. ${ }^{49}$ 그러나 히로시마 시 행정당국의 움직임은 처음에는 어디 까지나 전재도시 부흥에 관한 것으로 원폭피해자들에 대한 원호 등에 관한 것은 아니었다. 당시 전재도시 부흥의 문제는 건설성을 중심으로 일본 정부 가 추진하고 있던 전재부흥의 일환으로, 당국은 아시아-태평양전쟁 기간 중 본토 공습으로 인해 약 120 개 도시가 피해를 입고, 피해를 입은 가구 수 도 전체 $20 \%$ 에 이른다고 파악하고 있었다. ${ }^{50}$ 히로시마 시 행정당국의 원폭 재해종합부흥대책이 다른 전재도시 부흥계획과 차별화되어 특별하게 취급 될 수 없는 상황이었다는 것이다. 다만 히로시마 시 행정당국은 종전 직후 의 하마이(浜井) 와타나베(渡辺) 시정 하에서 원폭피폭자를 위해 진정활동 과 원대협 활동을 지원하는 등의 활동을 벌이기는 했다. 그러나 이들 또한 원폭피해자들에 대해 직접적인 지원정책을 취하지는 않았다. ${ }^{51}$

전재민들에 대한 원호 문제에 일본 정부가 '나서지 않는' 혹은 '나설 수 없는’ 상황은 당시 일본에 주둔해 있던 승전국 연합군사령부의 존재도 한 요인이었다. 특히 전쟁 당시의 피해에 대한 보상 문제는 전적으로 승전국 지도부 소관의 일로 패전국인 일본이 먼저 나설 수 없었다. 일본 당국은 당 시 연합군사령부의 지시로 제국시절의 군사관련 법령을 모두 폐지한 상태 였기 때문에 이전의 군인연금, 상이군인에 대한 지원, 전쟁피해자에 대한 보상 등을 포함하고 있던 모든 보상 조치를 중지하고 있었다. ${ }^{52}$

이 같은 상황에서 전후 일본 사회에서 전쟁피해자와 관련된 원호와 보 상 문제가 본격적으로 제기된 것은 미국과 일본의 강화조약 체결을 즈음한 1950 년대 초반이다. 강화조약의 조인을 앞 둔 1951년을 즈음해 연합군의 점 령으로 인해 잠복해있던 전후 처리와 관련된 문제들이 정치상의 과제로 떠 올랐다. 그중에서도 전쟁희생자에 대한 국가의 조치는 가장 큰 문제였다. ${ }^{53}$

그러나 이처럼 샌프란시스코강화조약 이후 전후 전쟁피해자와 관련된

49 広島県原爆被爆者団体協議會, 『原爆被爆者対策事業概要』, 362票.

50 根本雅也, 『広島の戦後三○年間にみる原爆被害の表象と実践』, 12至.

51 広島県原爆被爆者団体協議會, 『原爆被爆者対策事業概要』, 99䂬.

52 広島県, $『$ 被爆40年原爆被爆援護のあゆみ』, 37空.

53 広島県, 『被爆40年原爆被爆援護のあ以み』, 37空. 
일본 정부의 원호 문제가 활발하게 논의되고 실질적인 보상으로 이어졌지 만, 이때도 원자폭탄의 피해자들이 전쟁 피해와 관련된 원호 조치를 받을 대상이라는 범주에 들지는 않았다. 당시 원폭으로 인해 다수의 전쟁희생자 가 있었던 히로시마 시와 나가사키 시에서는 일반 피해자들뿐만 아니라 이 들의 요구를 기반으로 정책을 입안하는 시행정당국 또한 일반의 '전몰상자' 를 포함해 '원폭사상자' 조사를 행하고 그 실태를 밝히는 것을 비롯해 이들 희생자에 대한 국가의 원호를 기대하고 있었다.54 그러나 일본 정부는 전후 보상과 원호법은 군인과 군속, 준군속의 희생자만이 대상이 되는 것이었기 때문에 그 대상에서 민간인은 제외되며, 일반 시민으로서의 '원폭장해자'는 다른 민간인 전쟁희생자와 마찬가지로 국가 보상과 원호의 대상이 되지 않 음을 분명히 했다. 이는 당시 일본 정부가 전쟁피해와 관련한 개인 보상의 문제를 '과거에 국가에 의한 고용관계에 있었거나 또는 그에 준한다고 간주 되는 자'에 한정하여, 그 이외의 경우를 배제했기 때문이다.55

\section{4. '원폭장해자'에서 '원폭피폭자'로}

1) 비키니 피재와 피폭된 신체

히로시마와 나가사키에 원자폭탄이 투하된 지 12년이 지난, 1954년 3월 1일, 마샬군도 비키니 환초에서 행해진 미국의 수소폭탄 실험으로 근처에서 어 업활동을 하고 있던 제 5 후쿠류마루(第五福竜丸)에 승선했던 23 명의 어부들 의 피폭, 일명 비키니 피재(ビキニ一被災) 사건이 발생한다. 연합군의 점령이 해제된 이후 2 년 만에 벌어진 이 사건은 피폭된 어부들의 급성방사능증 발 병과 악화 그리고 사망으로 이어진 충격적인 사태의 전개, 그리고 또한 일 본인들이 사랑하는 참치잡이 어선의 피폭이라는 점에서 곧 방사능으로 오

54 広島県, 『被爆40年原爆被爆援護のあゆみ』, 37 쪽.

55 赤澤史朗, 「전몰자 추도와 야스쿠니 신사」, ${ }^{\circledR}$ 공익과 인권』 제 3 권 제2호, 2006, 66 67쪽. 
염된 식탁의 문제로 확장되면서 원수폭금지서명운동 및 원수폭금지세계대 회 개최 등으로 이어지고 이후 일본 사회의 풀뿌리 반핵 및 평화운동의 도화 선이 되었다고 평가된다. 또한 이 같은 원수폭금지 여론의 고양과 더불어 히 로시마와 나가사키의 원폭피해자들의 원호책 마련에 대한 사회적 지지도 높 아졌다. 비키니 피재 후 결성된 일본피폭자단체협의회(이하 일본피단협으로 약 칭) 발족 직후 원폭피해자원호법안요강을 발표하는 등 원폭피해자의 국가보 상을 국가에 압박하는 활동을 전개하고, 그것이 원수폭금지운동의 고조와 히로시마 및 나가사키 등의 지방 정부의 움직임과 결합해 원폭피해자 대책 을 국가에 요구하는 원동력이 됐다는 점도 이를 방증한다. ${ }^{56}$

그러나 계기라 하는 것이 단순히 비키니 피재 사건 모든 것의 출발점이 라는 의미는 아니다. 그보다는 이 사건이 히로시마와 나가사키의 원자폭탄 투하 이후 소규모의 지식인과 행정 당국, 피해자 일부를 중심으로 이뤄지고 있던 여러 실천과 표상들이 전국적으로 전개되어 나가는 과정의 중요한 한 결절을 이루면서 증폭제 역할을 했다는 평가가 더 적절해 보인다. ${ }^{57}$ 더불어 여기서 좀 더 주목해야 할 점은, 비키니 피재 사건을 통해 원폭피해자구호 제도가 필요하다는 공감을 얻어가는 과정에서 나타난 특정 방식의 굴절에 관한 것이다.

비키니 피재 사건은 히로시마와 나가사키의 원폭과는 분명히 다른 점이 있었다. 우선 사건의 피해자와 가해자라는 구도에서 봤을 때는 무엇보다 새 로 개발한 수소폭탄의 위력을 평가하기 위해 실험을 하고, 거기에서 민간인 이었던 일본 어부들이 피폭을 당해 사망에 이른 것이 분명했다. 원폭 투하의 주체였던 미국이 '아시아 여러 나라에 피해를 입힌 전쟁의 종결과 전 세계 의 평화'를 위해서였다고 정당화한 히로시마와 나가사키의 원폭 문제에서 는 피해를 본 이들이 곧 전쟁을 개시한 국가의 국민이면서 패전국의 전재민 일 뿐이었다. 그 때문에 미국은 앞서 히로시마와 나가사키의 원폭피해자들

56 竹峰誠一郎, 「“被爆者”という言葉がもつ政治性」, 21 23兲.

57 根本雅也, 『広島の戦後三○年間にみる原爆被害の表象と実践』. 
이 요구한 피해보상에 대해 패전국인 일본은 전쟁과 관련한 어떠한 손해나 보상, 배상도 미국에 요구할 권리가 없다는 샌프란시스코 강화조약을 들어 대응한 적이 없었다. 그런 미국 정부가 비키니 피재 사건 후 피폭 당한 어부 가 사망에 이르자 즉각 피해자들에 대한 금전적인 보상책을 마련한 것이다.

신체적 영향면의 피해에 대해서도 다르다는 의견 역시 개진됐다. 비키 니 피재 사건이 이슈가 되고 처음 열린 중의원 후생위원회 회의에서는 비키 니 피재 사건으로 피폭된 어부들의 상태 등과 관련해서 심도 깊은 논의와 질 의가 이어졌다. ${ }^{58}$ 이 날 회의에서 특히 중요한 문제는 어부들이 수소폭탄 ${ }^{59}$ 의 폭발실험으로 영향을 받을 것으로 예측되어 어업활동이 금지된 구역 밖에 서 활동하고 있었고, 폭발이 있었던 당시에는 직접적인 외상이 없이 어업활 동을 마치고 돌아왔음에도 불구하고, 급작스런 피폭으로 인한 급성방사능증 으로 여겨지는 상태를 보인다는 점이었다. 이에 당시 원폭피해자들을 오랫 동안 치료해오면서 원자폭탄증 관련 연구에 독보적인 권위를 가졌던 쓰즈키 마사오 교수가 참고인 자격으로 나와 관련 문제에 대해 언급했다.

쓰즈키 교수는 어부들이 폭탄의 직접 영향권에는 있지 않았으나 그들이 보이고 있는 증세는 확실히 '피폭으로 인한 급성방사능증'인 것으로 여겨 지며, 이와 관련해서는 조심스럽지만 '원자력 실험으로 인해 생겨난 것으로 보이는 재(灰)'가 원인일 수 있다는 의견을 제시한다. 덧붙여 그는 “오해를 방지하기 위해” 히로시마와 나가사키의 원폭은 지상 높은 곳에서 폭발해 폭 발 순간에 발생한 열과 폭풍, 방사능에 의해 직접적인 피해를 입은 것이며 재는 거의 지상으로 떨어지지 않아 그와 관련된 피해는 다행히 적었다. 이 것은 원자폭탄증이라고 할 수 있으나, 후쿠류마루의 어부들은 직접적인 원 자폭탄의 폭발로 인한 피해가 아니라 원자력 실험으로 인한 핵분열생성물 의 낙진, 즉 방사성 재를 뒤집어쓰게 되어 나타나는 급성방사능증으로 구분 해야 한다는 말로서 증언을 마쳤다.

58 1954년 3월 22일, 제19회 국회 중의원 후생위원회 회의록 제18호(일본국회 http://kokkai.ndl.go.jp/).

59 같은 회의록에서 보면 당시에는 이 실험에서 사용된 폭탄에 대한 정보가 정확하지 않았던 것으로 보 인다. 원문에는 ‘원자력 실험’이라고 언급되고 있다. 
쓰즈키 교수의 국회 증언이 있은 후 방사능의 위험에 대한 사회적 관심 과 공포 그리고 원자병기의 금지에 대한 여론은 더욱 높아졌다. 비키니 피 재 사건 후 일본에서 전국적으로 전개된 원수폭금지서명운동의 시초가 된 도쿄도 스기나미구(杉並区) 주부들의 움직임은 그 출발을 알리는 신호였다. 이들은 비키니 피재는 원자병기에 의한 일본 국민의 피해이며, 그러한 점에 서 히로시마와 나가사키에 이은 ‘세 번째 피해’라고 규정했다. 전국적인 서 명운동이 전개되고 그 과정에서 원수폭 금지 운동은 일본이라는 국가 수준 으로 강조되었다.

무엇보다 중요한 것은 원자병기에 의한 피해자, 곧 원수폭피해자와 방 사능에 의한 피해가 초점이 되어 갔다는 점이다. 이는 원수폭피해자 관련 단체 결성에 의해 더욱 강화되었다. 또한 원폭생존자로서 원수폭피해자들 이 운동의 중심에 서게 되면서, ‘원폭피해를 밝히는 것', '원수폭금지', '피해 자구원' 등으로 분리되어 있던 그간의 실천들이 생존자였던 원폭피해자들 의 신체로 집약되기 시작한다. ${ }^{\circ}$ '어떤 대표도 아닌 피해자로부터 직접 듣 는 실상이 의사나 학자로부터 듣는 것보다 훨씬 원폭의 무시무시함을 느낄 수 있고, 마음 깊숙한 곳으로부터 원자병기를 금지해야만 한다는 것은 고통 스러운 생활을 하고 있는 원폭피해자에게 사랑의 손길을 뻗치는 것이라 생 각한다라는 등의 발언이 힘을 얻었다.61 이처럼 비키니 피재 사건은 일본 사회에서 원폭피해자를 사회적 공론의 장에 끌어들이고, 무엇보다 이들의 신체를 방사능의 피해를 입은 것으로 조명하는 계기가 된다.

비키니 피재 사건은 또한 일본 국회에서 피폭자라는 용어가 법제적으로 검토되고 상용화되는 계기를 만들었다. 이는 일본의 중의원과 참의원 회의 록을 통해 확인할 수 있다. 1954년 3월 18일에는 피폭된 어부들이 사망에 는 이르지 않았으나, 급성방사능증으로 인해 병세가 매우 악화되어 있다는 것이 연일 언론에 보도되는 시점이었는데, 이 날 참의원 후생위원회 회의에

60 根本雅也, 『広島の戦後三○年間にみる原爆被害の表象と実践』, 66 67空.

61 竹峰誠一郎,「被爆者’という言葉がもつ政治性」. 
서는 처음으로 관련한 회의가 열렸다. ${ }^{2}$ 회의에 참석한 정부 담당자들에게 의원들은 긴급 현안 질의로 비키니 수폭 실험으로 인해 어업환경이 괜찮은 지, 방사능의 피폭으로 인한 어산물 피해가 어떨지 등에 대해 주로 물었는 데, 이에 대해 구사바 류엔(草葉隆圓) 당시 국무대신은 '방사능이 어장 생태 에 어떤 영향을 미쳤고 이것이 사람에게 어떤 영향을 미치는지에 대한 연구 는 충분하지 않지만, 일단 이 근처에서 잡은 생선을 시판하는 것은 금지하 는 조치를 취했다'고 설명했고, 이에 피폭당한 환자들의 상태를 점검하라는 수준의 주문이 이뤄졌다. 이 날은 일본의 양원 국회 회의록에서 피폭자라는 용어가 처음으로 등장한 날이며, 이후로는 이 용어가 급격하게 높은 빈도로 사용되고 있음을 확인할 수 있다.

이 같은 사태의 전개를 굴절63이라는 측면에서 보자면, 비키니 피재 이 후 패전국의 전재민이었던 일반의 원폭상해자들이 원자병기에 의해 피폭 당한 자로서의 특수성이 부각되기 시작했다는 점을 지적하지 않을 수 없다. 비키니 피재가 히로시마와 나가사키의 원폭과는 다른 점이 분명히 있었음 에도 불구하고, 원자병기 그리고 그것의 표어가 동일성, 특히 핵심인 방사 능의 피해는 동일성의 핵심을 이루는 것이었다. 비키니 피재를 계기로 부상 한 방사능의 공포에 대한 사회적 여론이 이전과는 완전히 다른 수준에 이르 렀다는 점에서 이는 일종의 사회적 매질의 변화였으며, 원폭피해자들의 운 동 방향을 굴절 시키는 효과를 가졌다고 할 수 있다.

비키니 피재는 기존의 원폭피해자운동과 방사능에 대한 사회적 여론을 변화시킨 것뿐만 아니라, 피폭과 핵병기에 대해 일본 정부가 입장을 표명 할 것을 요구하는 것이기도 했다. 이에 일본 정부는 표면적으로는 명백하게 반핵이라는 입장을 취해 나가기 시작한다. 또한 방사선의 위험에 대한 사회 적 관심과 냉전의 긴장 또한 높아지던 시기에 이러한 입장은 결국 핵공격

62 1954년 3월 18일, 제19회 참의원 후생위원회 회의록 18호(일본국회 http://kokkai.ndl.go.jp/).

63 이 용어의 물리학적 의미는 특정한 에너지 파동이 매질의 밀도에 따라 다른 형태로 전개된다는 것이 지만, 일반적으로 예를 들 수 있는 것은 빛이 매질이 변화에 따라 특정한 방향으로 바뀌어 진행한다 는 것이다. 
이라는 사고로 인해 피해를 입은 일본인 그리고 일본국이라는 인식으로 이 어졌다. 그러나 이 과정에서도 여전히 이 같은 '세 번째 피폭', '20세기의 비 극', '세계 평화의 출발지', '유일피폭국'과 같은 언설들을 주로 채택한 곳은 일본의 중앙 정부보다는 히로시마와 나가사키, 그리고 시즈오카라는 세 개 의 현과 시민운동 단체들이었다. 이들은 일본국 그리고 일본 정부가 이러한 언설들에 걸맞는 국가로서의 책임을 다할 것을 압박해 나간다. 그리고 이러 한 분위기 속에서 전후 피식민국과의 관계에서 과거의 식민 지배와 전쟁 수 행에 대한 어떠한 책임에서도 애매모호한 입장을 취하고 있던 일본 정부는 '유일피폭국'이라는 표어를 집어 듦으로써64 제국주의 과거를 소거(消去)하 고 국가화 된 피해자 담론 속에 안착했다.

전후 미소 냉전체제와 핵안보체제 하에 편입되어 전후 부흥을 도모한 일본 정부가 표면적으로는 비핵화한 나라로서 도덕적 지위를 강조하고 평 화를 외침으로써 외부로부터의 비난에서 한 발짝 물러나 있으려고 한 것이 다. 물론 비키니 피재 후 원폭피해자들이 중심이 된 반핵평화운동과 이러한 사회운동의 상징인 원폭피해자를 방치하고 있다는 선언들은 일본 정부를 매우 당혹스럽게 했지만, 한편으로는 일본 정부가 그러한 선언들에 최소한 의 대응을 하는 모습을 보여줌으로써 유일피폭국이라는 피해자로서 중요한 정치적 수사로서 구비되기 시작한다.

\section{2) 새로운 자격의 범주로서 '피폭자'}

비키니 피재 이후 일본 정부는 원폭피해자구호정책의 수립 과정에서 반핵 평화운동단체나 원폭피해자 단체들이 사용하던 원자폭탄피해자나 원폭환 자, 원폭피재자, 원폭상해자, 원폭장해자 등과 같은 용어가 아닌 원자폭탄 피폭자, 즉 그 단어를 줄여서 오늘날 일반적으로 사용되고 있는 피폭자라는 단어를 특정했다. 원폭의료법이 제정되기 이전까지 피폭자라는 용어가 일

64 Maya Todeschini, "Illegitimate Sufferers: A-bomb Victims, Medical Science, and the Government", Daedalus, Vol. 128, no.2, p.67 100. 
본 사회에서 일반적으로 사용되는 개념은 아니었다는 점에서, 이 용어는 적 어도 이전까지 사회적 공론의 장에서는 존재하지 않았던 새로운 구성원 범 주 혹은 새로운 자격의 범주가 탄생했음을 의미했다.

1957년에 제정된 일본의 원폭의료법은 피폭자를 '피폭자건강수첩의 교 부를 받은 자다'(제2조)라고 정의했다. 그리고 여기에서 원폭피폭자건강수첩 을 교부받을 수 있는 자격은 크게 네 개의 종류로 분류됐는데, 다음과 같다. 첫째, 1 호, 원폭투하 당시에 히로시마 시 혹은 나가사키 시의 구역 내 혹은 정부 시행령으로 정한 이 두 도시의 인접 구역 내에 있었던 자. 이들은 직접 피폭자로 불린다. 둘째, 2 호, 원자폭탄이 투하된 때부터 계산하여 정부 시행 령에 정해진 기한 내에 앞에서 규정된 구역 내에 있는 정부 시행령에 정해 진 구역에 있었던 자. 입시(入市)피폭자로 불린다. 셋째, 3 호, 앞에서 규정된 사람 이외에 원자폭탄이 투하된 때 혹은 그 후에 신체에 원자폭탄의 방사능 영향을 받을만한 사정 하에 있었던 자. 구호피폭자로 불린다. 그리고 마지 막으로 4호, 피폭자에 해당하는 것으로 인정되는 그 사람의 당시 태아, 이들 은 태내피폭자로 불린다. 이러한 규정은 원폭의료법이 시행된 1958년부터 원폭원호법으로 변경된 이후에도 그대로 사용되고 있다.

중요한 것은 이 법적 규정에서 피폭자를 '방사능 영향을 받은 자'라는 규정에도 불구하고, 그것의 기준은 '구역 내' 혹은 '기한 내'라고 되어 있다. 이는 히로시마와 나가사키의 피폭자가 방사선량이나 체내피폭량 등과 같 은 의학적 수치가 아니라 특정한 장소와 시간 범위를 통해 규정된다는 것 을 의미하고, 이 장소와 시간이 방사선 영향의 지표가 됨을 의미한다. 때문 에 원폭의료법 시행 이후 지금까지 이 '구역'과 '기한'의 범위에 대한 경계 는 관련 당사자 간의 끊임없는 분쟁의 영역이 되어 왔다. 그리고 추세적으 로 히로시마와 나가사키에서 그 구역은 지속적으로 확대되는 경향을 보이 고 있다.65

65 일본 원폭피폭자원호에 관한 법률 및 세부 시행령, 구역 변화는 다음의 법령 자료 참조. 被爆者援護 法令研究会, 『原爆被爆者関係法令通知集』, 2003. 
한편, 이렇게 '피폭자'라는 개념에 법적이고 표준적인 정의를 선언한 원 폭의료법의 제정은 이것이 단순히 특정한 형태의 어떤 인구집단에 대한 수 사적이고 개념적인 차원의 경계짓기가 아니라, 국가가 이들에게 공인된 법 적 자격을 부여하고 한계를 지움으로써 관련된 여러 자원의 불균등한 배분 을 구체화하고 정당화하는 경계짓기를 의미했다. ${ }^{66}$ 피폭자건강수첩은 그 사람이 원자폭탄 피폭의 생존자인지를 판명하는 증명서의 일종으로 법적으 로 그 개인의 원자폭탄 피폭의 경험을 인증67하는 중요한 매체가 되었다.

피폭자의 자격을 피폭자건강수첩을 교부 받은 자로 제도화시킨 이 지 점은 그 이전까지 국가에게 피해를 보상할 것을 요구해왔던 원폭피해자들 이 이제 지원의 대상이 되고, 국가는 국가가 제공할 자원들을 수급할 자격 의 범주를 구성하고 통제하는 좀 더 강력한 주체로 자리매김했음을 의미한 다. 피폭된 신체라는 상태가 아니라 수첩이라는 관료제적 증명서가 피폭자 를 만드는 것이다. 이제 국가는 이 수첩을 받을 수 있는 사람과 없는 사람을 구분하는 기준, 즉 피폭자의 경계를 만들고 통제하는 행정관료적 주체로 등 장한다. 이제 이 행정관료적 주체로서 국가는 법적 정의와 행정적 실행 규 칙, 관료제적 심사 절차 등을 통해 피폭자건강수첩을 교부받은 자로서 피폭 자를 인증하게 된 것이다.

한편, 일본에서 원자폭탄의 피해자에 대한 보상이나 지원 수준을 결정 하고, 그 대상이 되는 범주의 경계를 한정짓는 행위는 전전의 국가 행위에 대해 정치적으로 평가해야 함을 전제하는데 이는 매우 민감하고 복잡한 맥 락 속에 놓여 있었다. 앞서 살펴본 바와 같이 샌프란시스코강화조약 이후 전쟁피해자와 관련된 일본 정부의 원호 문제가 활발하게 논의되고 실질적 인 보상으로 이어졌지만, 이때에도 원자폭탄의 피해자들이 전쟁 피해와 관 련된 원호조치를 받을 대상이라는 범주에 들지는 않았다. 미국 또한 앞서

66 Michael Lynch, "Circumscribing expertise: Membership categories in courtroom testimony" in Sheila Jasanoff ed., States of Knowledge: The co-production of science and social order, Routledge, 2004, p.162 165.

67 Yoneyama, Hiroshima Traces, p.93. 
히로시마와 나가사키의 원폭피해자들이 요구한 피해보상에 대해 패전국인 일본은 전쟁과 관련한 어떠한 손해나 보상, 배상도 미국에 요구할 권리가 없다는 샌프란시스코 강화조약을 들어 대응한 적이 없었다.

비키니 피재 직후 원폭피해자들이 국가를 상대로 제기한 원폭피폭에 대 한 손해배상 청구소송(일명 '도쿄원폭재판')은 이 같은 논쟁이 가로지르는 쟁점 들을 잘 보여준다. 당시 재판부는 이들의 손해배상청구권은 강화조약으로 방기된 것으로서 기각되었으나 원폭 투하는 국제법 위반이라고 해석했다. 또한 원폭피해자는 "피해의 심대함은 도저히 일반전재와 비교가 되지 않는 다. 피고는 여기에 비춰 충분한 구제책을 내놓아야 한다는 것에 다언을 요 하지는 않을 것이다”라며 국가가 이들에 대한 구제책을 강화해야 한다는 판 결을 내놓았다. 하지만 일본 정부에게 이 '피해의 심대함'을 구분 하는 문제 는 단순히 생의학적 측면에 한정되지 않았다. 즉 일본 정부가 원폭피해자들 에 대한 원호를 제도화 하는 데 있어, 제국 일본이 수행한 전쟁의 민간인 피 해자들과 달리 원폭의 피해자들만을 대상으로 하는 것에 있어 국내 정치적 으로 이를 정당화할 명목이 필요했다.68 결론적으로 이러한 요구에 대해서 일본 정부는 국내적으로는 국가가 행한 전쟁 수행에 대해서는 책임을 물을 수 없으며, 전쟁으로 인한 일반의 피해는 어쩔 수 없다는 이른바 수인론(受 忍論)을 내세우고, ‘원자폭탄의 피해’는 극히 ‘특수한 피해’라는 점을 강조해 나갔다. 즉 이는 역으로 특수한 피해로서 원자폭탄의 피해는 언제나 '일반 의 피해'와의 균형 속에서만 보상되고 지원될 수 있음을 의미한다.

68 일반의 전재민과 원폭피해자를 구분하여 원호하는 것에 대한 반발이 얼마나 일반적인지를 설명하기 는 쉽지 않지만, 다음의 사례는 그 기저에 깔린 감정을 짐작하게 한다. 2007년 겨울 연구자는 조사를 위해 나가사키의 한 숙소에서 머물렀었는데, 당시 그곳 주인이었던 친절한 한 중년의 남성은 "왜 '피 폭자'들만 특별취급을 받아야 하는가, 전쟁 때는 모두들 고생을 했고 '피폭자'들보다 더 피해를 많이 입은 사람들도 아무런 정부 지원 없이 살아가고 있다”라며 연구자가 ‘특별히' 히로시마와 나가사키 의 원폭피해자 문제에 대해 관심을 있다는 사실을 못마땅해했었다. 일본이 벌인 전쟁은 '동양 문화 를 지켜내려는 성전(聖戰)'이었다는 신념을 확고하게 지닌 그에게 나가사키의 원자폭탄 피해는 미 국과 연합국에 의한 다른 공습 피해와 특별히 다를 바 없는 것이었다. 그런 히로시마와 나가사키를 원자폭탄의 도시로만 기억하는 것이 그는 불만이었다. 그러나 그의 정부는 표면적으로라도 오랫동 안 이 두 개의 폭탄은 특별하다는 입장을 취함으로써 정치적으로 또 외교적으로 잠시나마 피해국이 된 안도감을 누렸기 때문이다. 그러나 이러한 표면적인 입장과 도덕적 선언에도 불구하고 일본 정부 의 '비핵'(非核)원칙에 대한 입장은 언제나 애매하게 유지됐다. 
'피폭자 특수주의'의 저울질 과정이라고도 이해할 수 있는 이 과정은 일 본의 원폭피해자구호정책의 근간이 되는 원폭의료법과 원폭특별조치법, 그 리고 이 둘을 결합해 새로 제정된 원폭원호법에서 "원자폭탄이 투하된 때 혹은 그 후에 신체에 원자폭탄의 '방사능 영향'을 받을 만한 사정 하에 있었 던 자”, 즉 피폭자의 신체적 상해가 그 피해를 지원하는 것의 핵심을 이룬 다는 점에서도 확인할 수 있다. 따라서 이는 실제 원폭피해자 구호정책에서 ‘원자폭탄의 특수한 피해로서의 신체적 상해’의 경계가 어디인지 설정해야 함을 의미했다.

또한 원폭피해자구호의 정치적 민감함은 일본의 국내적 차원이 아니라 한 때 대일본제국에 속해 있었으나 현재는 국적과 거주하는 영토도 다른 옛 신민들과의 탈식민지적 관계 속에 얽혀들었다. 1970년대에 진행된 손진두 소송과 현해탄을 넘어 일본으로 밀항한 한국원폭피해자들의 존재는 전후 일본 정부가 전전의 대일본제국이라는 국가를 맞닥뜨리게 한 중요한 정치 적 사건이었다. 이러한 정치적 사건들 속에서 일본 정부는 그간 회피해왔던 ‘옛 피식민국의 신민'의 존재, 즉 한국과 대만, 중국, 북한 등지로 귀환한 원 폭피해자들, 전후 생계를 위해 브라질이나 미국 등지로 이민 간 일본 국적 의 원폭피해자들, 그리고 전쟁 당시 유학이나 포로 등으로 끌려왔다가 자국 으로 송환된 미국이나 영국 등지의 원폭피해자들을 직시해야 했다. 이와 관 련해서 일본 정부는 피폭자 범주에 속할 수 있는 자격으로 일본 영토적 경 계 안에 거주하거나 일정기간 거류할 것을 명시하는 행정관료제적 규칙을 만들어냈다, 이후 일본 영토 밖에 거주하는 과거 피식민국의 신민과 해외에 거주하는 원폭피해자들을 배제해 나갔다.

피폭자 범주에서 배제된 과거 '제국의 신민’이자 '피식민자'들의 존재에 문제가 된 것은 이른바 한국원폭피해자에 대한 피폭자건강수첩 교부 문제 를 두고 불거진 손진두 소송에서 가장 극명하게 전개됐다.

수첩재판이라고도 불리는 이 소송은 1972년 10월 2일 부산에 거주하 던 손진두 씨가 원폭증의 치료를 위해 일본으로 밀입국한 뒤 체포되었다가, 일본 시민단체들의 도움을 받아 후쿠오카 현 지사를 상대로 피폭자건강수 
첩의 교부를 신청했다가 각하된 것을 계기로, 각하처분 취소소송을 후쿠오 카지방재판소에 제기한 것을 말한다. 수첩 교부 각하가 결정되었던 1972년 7월 14일 일본 후생성은 "원폭의료법의 취지는 법에서 규정하는 조치를 실 시하는 것으로 지역사회의 복지 향상을 도모하는 데 있고, 동법의 적용을 받는 자는 지역 사회와의 결합관계(거주관계)가 있을 것이 요건으로 되어 있 는데, 손진두의 일본국내 체류 사실은 동법이 예정하고 있는 거주 관계가 아니며, 따라서 당신에게는 동법이 적용되지 않는다”는 이유로 손진두가 후 쿠오카 현에 신청한 피폭자건강수첩 교부를 각하하면서 시작된 것이다.

재판에서 원고인 손진두 측의 변호인은 "원폭의료법은 1945년 8월 6일, 9일에 피폭자가 가지게 된 일본국에 대한 보상청구권에 관하여, 그 범위를 정한 뒤 구체적인 절차를 정한 것으로 해석된다. 그리고 동법의 취지가 그 러한 이상 피폭된 모든 인간이 국적, 현재의 거주 장소 기타 일절 차별 없 이 동법이 정하는 이익을 향수할 권리를 가진다고 하지 않으면 안 된다"고 주장했다. 그리고 이렇게 시작된 이 소송은 1978년 3월 30일 최고재판소에 이르기까지 모두 세 번의 승소 판결을 받게 된다.

판결 당시 일본 최고재판소는 원자폭탄의 피폭으로 인한 건강상의 장애 는 전쟁이라는 국가의 행위로 이루어진 것임을 전제로 하여, 원폭의료법은 "원폭과 같은 특수한 전쟁피해에 대해서는 전쟁수행의 주체였던 국가가 스 스로의 책임에 의하여 그 구제를 꾀한다는 일면이 있고, 원폭의료법은 실질 적인 국가 보상적 배려가 제도의 근저에 있다는 것을 부정할 수 없는 것이 다"라고 하여 원폭피해에 대해 국가가 보상하는 것이 국가의 의무임을 인정 하였다. 즉 당시에 존재하고 있던 원폭의료법과 원폭특별조치법이 소위 사 회보장법으로서의 다른 공적 의료급부입법과 같은 성격을 가지고 있지만, 국가 보상적 배려 또한 제도의 근저에 있다는 것을 인정한 것이다. 특히 재 판부는 이것이 "피폭자만을 대상으로 특별히 우위법이 된 이유를 이해하는 것"에 대해서는 “원자폭탄의 피해에 의한 건강상의 장해가 역시 예를 찾아 볼 수 없는 특이하고 심각한 것이라는 점과 함께, 관련된 장해가 전쟁이라 는 국가의 행위에 의해 초래되었다는 것이며, 더욱이 피폭자의 다수가 지금 
현재까지도 생활상 일반의 전쟁피해자보다도 불안정한 상태에 처해져있다 고 하는 사실을 빠뜨릴 수 없다"라고도 기술하고 있다. ${ }^{69}$

손진두 소송에 있어 일본 사법부의 이 같은 법률 해석은 곧 일본의 원폭 피해자구호정책의 근본적인 변화를 필요로 하는 것이었다. 종전까지 이 법 이 사회보장제도의 일환이라고 주장해왔던 일본 정부는 이제 이 법의 '특 수한 성격'에서 비롯되는 '국가 보상적 배려'에 대해 고민해야 했다. 국회는 즉각 원폭특별조치법의 개정에 나섰다. 그러나 법의 개정안이 "원자폭탄피 폭의 특수성”에 대한 검토가 부족하다는 의견이 제시됐다. 1979년 1월 정 부에서 마련한 개정안에 대해 사회보장제도심의회는 "금회의 개정안은 국 회의 부대결의에 따라 제수당의 증액을 비롯해 상당한 진전이 있었다고 인 정된다. 그러나 본심의회가 지적해온 바에도 불구하고 피폭자에 대한 제도 의 기본적인 형태에 대해 아직도 충분한 검토가 되지 않았다는 것은 유감이 아닐 수 없다. 정부에 있어서는 원자폭탄피폭의 특수성에 관해 전문가에 의 한 권위 있는 조직을 설치해, 1978년 3월의 최고재판소의 판결(손진두 소송) 의 취지를 토대로 조속히 이 문제에 관한 기본이념을 명확히 하는 것과 함 께 현행2법의 재검토를 행해야 할 것이다”라고 답신한다.

이에 대해 후생대신은 1979년 6월 도쿄대학 명예 교수 2인, NHK 해설 위원, 도호쿠학원대학 교수, 전 최고재판소 판사, 전 프랑스 대사, 원자력안 전위원회 위원(총 7인)으로 구성된 '원폭피폭자대책기본문제간담회'를 발족 시켰다. 간담회에서 문제가 된 것은 전쟁피해로서 원자폭탄피폭이 갖는 특 수한 성격을 어떻게 이해하고 그와 관련한 '국가'의 역할이 무엇인가에 대 한 것, 즉 원폭피폭자 대책의 '기본이념'이었다. 1980년 12월 11월 후생대 신에게 제출된 의견서는 이와 같은 고민을 잘 담아내고 있다. ${ }^{70}$

대체로 전쟁이라는 국가의 존망이 걸린 비상사태라는 것에 있어서 국민이 생 
명, 신체, 재산 등에서 그 전쟁에 따른 어느 정도의 희생을 감수하는 것은 어쩔 수 없는데, 그것은 전국가적인 전쟁에 의한 “일반의 희생”으로서, 모든 국민이 다 같이 감내하지 않을 수 없는 것으로서, 정치론적으로 국가의 전쟁 책임 등을 운운하는 것은 물론 법률론으로서도 개전, 강화 등과 같은, 소위 정치행위(통치 행위)에 대해 국가의 불법행위책임 및 법률상의 책임을 추급해 그 법률적 구제 를 구하는 등은 개시되지 않는다고 할 수밖에 없다. ${ }^{71}$

그런데〈간담회〉의견서에서 볼 수 있듯이, 일본 정부는 손진두 소송에 서 패소했음에도 불구하고 사실상 앞서 도쿄재판 이후 국가가 '국가 보상적 성격'을 인정하라는 것을 부정한 것과 동일한 논리로 여전히 이 국가 보상 의 논리를 최소화하고자 했다. 손진두 소송에 있어 원폭의료법과 원폭특별 조치법이 국가 보상적 배려에 근거하고 있다는 일본 사법부의 판단은 행정 에서 다시 재해석된다.

(전략) 그렇다면 원폭피폭자대책은 어떠한 기본이념에 근거해 행해져야하는 것 일까. 종래 정부는 현행 원폭2법에 의한 대책은 다른 일반전재자에 대한 대책 과의 균형과의 조화 등을 고려해서인지 특별사회보장제도라고 하는 견해를 취 해 왔다...(중략)...최고재판소의 판결에도 기술되어 있는 것처럼, 종래 국가에 의 해 취해져온 원폭피폭자대책은 원폭피해라고 하는 특수성이 강한 전쟁손해에 착목한 일종의 전쟁손해구제제도로 해석되어야 하고 이를 단순히 사회보장제 도로 생각하는 것은 적절치 않다. 또한 원폭피해자의 희생은 그 본질 및 정도에 있어서 다른 일반 전쟁 손해와는 선을 그을 수밖에 없는 특수성을 갖는 "특별한 희생”이라는 점을 고려하면 국가가 원폭피폭자에 대해 “넓은 의미”에 있어서 국 가보상의 견지에서 피해의 실태에 대응하는 적절타당한 조치대책을 강구해야 한다고 생각한다. ${ }^{72}$

71 원폭피폭자대책기본문제간담회가 제출한「간담회의견서」(1980年 12 月 11日).

72 원폭피폭자대책기본문제간담회가 제출한「간담회의견서」(1980年 12 月 11日). 
의견서의 내용과 같이 간담회는 태평양전쟁으로 인한 일본 국민의 희생 은 매우 광범위 했고, 모든 국민이 그들의 생명, 신체, 재산 등에 대해 많든 적든 어느 정도의 희생을 감수했으나 그 같은 희생 중에서 히로시마 및 나 가사키 원폭투하에 의한 피폭자의 희생이 '극히 특수성이 강한 것'이었다고 보고 있다. 특히 이들은 '넓은 의미'에 있어서 이 법이 국가보상의 견지에서 이루어져야 한다고 했는데, 이것에 대해서는 몇 가지 추가적인 해설을 하고 있다. 우선 이 법이 국가보상의 견지에서 고려되어야 한다는 것이 "전쟁의 개시 및 수행에 관해 국가의 불법행위책임을 인정하는 것이거나, 원폭피폭 자가 위법한 원폭투하를 한 미국에 대해 가지고 있는 손해배상청구권의 강 화조약에 의한 방치에 대한 대상청구권을 인정한다는 의미가 아니라 금차 전쟁 과정에 있어서 원폭피폭자가 받은 방사선에 의한 건강장해 즉 '특별 한 희생'에 대해서 그 원인행위의 위법성, 고의, 과실의 유무 등에 관계없이 결과책임으로서, 전쟁피해에 상응하는 '상당의 보상'을 인정해야 한다는 취 지”라고 밝히고 있다.

간담회의 여러 제안과 관련해 논란 속에서 원폭의료법과 원폭특별조치 법은 여러 차례 개정을 거듭하였다. 고령화의 진행 등 피폭자를 둘러싼 환경 변화 및 현행 시책을 발전시킬 종합적인 대책을 강구할 것이 강하게 요청되 면서, 1994년 12월 '원자폭탄피폭자에 대한 원호에 관한 법률'이 제정되어 피폭자 건강관리 및 의료에 대한 원폭의료법을 제정하기에 이르렀다. 새로 운 법안에는 1980 년 간담회에서 제출했던 국가 보상적 배려에 관한 기본 이 념들이 충실하게 기술됐다. 그러나 이미 간담회에서 예견되었다시피, 이 법 에서 국가 보상적 배려는 여전히 '국가 책임에 있어 원자폭탄 투하의 결과로 서 생겨난 방사능에 기인하는 건강피해가 다른 전쟁피해와는 상이한 특수한 피해'라는 점에서 그것을 구제해야 한다는 요구에만 한정된다.

이처럼 전후 일본의 원폭피해자구호정책의 근간이 된 원폭의료법, 원폭 특별조치법, 원폭원호법은 국가 보상적 배려에 근거해 있다는 사법부의 판 단에도 국가 보상적 배려라는 전쟁 수행의 주체로서 전쟁의 불법 행위 등 과 관련된 피해가 아니다. 전쟁 수행 과정에서 생겨난 이른바 '전쟁손해', 
그 중에서도 '방사능의 피해'라는 특수한 피해에 대해 국가가 책임을 지고 보상해야 한다는 논리 속에 세워졌다. 이는 전후 일본 정부가 일관되게 전 쟁피해와 관련한 개인 보상 문제에서 민간인에 대한 보상을 제외한 논리와 일치한다. 때문에 일본의 원폭피해자구호정책 역사에서 피폭자라는 용어는 전시중의 국가가 개시한 전쟁에 대한 책임이라는 의미에서 국가보상적 배 려가 아닌, 방사능이라는 특수한 피해를 입은 이들에 대해 전후 국가가 '특 별히’ 그러나 ‘일반의 전재민'과 '균형'을 맞추어 '배려'한다는 의미를 갖는 다. 이로서 히로시마와 나가사키의 전재민들은 방사능의 피해자로 의미화 되고, 그 과정에서 과거 제국의 전쟁 책임은 소거되며, 오직 원자폭탄의 생 물학적 피해만이 유일한 국가보상적 배려 대상으로 한정되었다.

\section{5. 맺음말}

패전 직후 히로시마와 나가사키에 투하된 원폭에도 '살아남은 사람들' 즉 원폭생존자는 구호의 측면에서는 '일반의 전재민'들과 동일한 범주에 놓여 있었다. 반면 원폭생존자들의 방사능에 의한 인체 영향 연구는 원폭에 대한 시민방어라는 측면과 원자력의 평화적 이용이라는 미국의 새로운 정책적 관심을 반영한 미·일 공동의 주요 관심사가 되었다. 그러나 샌프란시스코 강화조약을 전후로 즈음한 원폭장해자 구호 움직임과 이어서 벌어진 비키 니 피재, 전국적인 반핵평화운동의 흐름은 그 이전의 과학 조사와 구호 활 동 속에서 전혀 주목받지 못하던 '피폭된 신체'에 대한 보상 문제를 전면에 등장시키게 된다. 이에 대해 일본 정부는 원폭피해자구호정책의 수립 과정 에서 반핵평화운동단체나 원폭피해자단체들이 사용하던 원자폭탄피해자나 원폭환자, 원폭피재자, 원폭장해자 등과 같은 용어가 아닌 원자폭탄피폭자 (오늘날 일반적으로 사용되고 있는 '피폭자')라는 단어를 특정했다.

원폭의료법이 제정되기 이전까지 피폭자라는 용어가 일본 사회에서 일 반적으로 사용되는 개념은 아니었다는 점에서, 이 같은 피폭자라는 용어는 
적어도 이전까지 사회적 공론의 장에서는 존재하지 않았던 새로운 구성원 범주 혹은 새로운 자격의 범주가 탄생했음을 의미했다. 물론 패전 후 히로 시마와 나가사키의 원자폭탄생존자에 대한 미국과 일본의 과학 연구들은 방사능의 노출이 인체에 미치는 영향이라는 연구 주제에 있어 고정되기보 다는 불안정적이어서 완전하지 않았다는 점에서 이 피폭자를 한정한 경계 는 고정되기보다는 '개념 짓는' 과정 속에 있었다. 그리고 그 과정에서 원폭 투하 직후부터 군부와 제국대학, 미국의 연구진들에 의해 수행되어온 과학 연구들은 원피해자구호정책이 행정적으로 실행되는 과정에서 원폭피해자 자신들의 신체와 기억, 그리고 기록이 무엇보다 중요한 제도화의 자원이었 다. ${ }^{73}$

또한 일본의 원폭피해자구호가 빠르게 법적 - 행정적 제도화 과정에 들 어서면서 일본의 국내외적 정치의 장에서 이 피폭자의 범주는 영토적 경계 안에서 개념화되었다. 일본 정부는 이와 관련하여 일본국 영토 바깥에 거주 하는 전후 과거 피식민자들의 원폭피해에 대한 보상요구에 대해서 '피폭자 의 자격은 일본국의 영토적 경계 바깥에 존재하는 이들에게는 부여되지 않 는다'는 이른바 시정권(施政權)의 논리를 들어 배제시켜 나갔다. 그러면서도 자국의 원폭피해자들의 원호 확대 요구에 대해서는 원자폭탄의 피해가 전 쟁으로 인한 일반의 피해와 구분되는 특수한 피해인 경우에 한정되어야 한 다는 수인론과 균형론을 내세웠다. 이렇게 커다란 두 축의 움직임은 일본 에서 피폭자가 갖는 정치·사회적 의미와 법적 규정이 과거 일본국이 수행 한 전쟁이나 식민지배에 대한 책임이 아니라 그 피해를 초래한 원인, 주체 도 명시하지 않은 원자폭탄생물학적 손상에 대한 보상에 한정된다. 즉 '제 국 일본'이 수행한 전쟁의 책임이 소거(消去)되는 과정으로 틀 지워짐을 의 미한다.

73 이 글에서는 일본에서 피폭자의 표상이 소위 '전후 일본'의 사회문화와 사상적 측면에서 역사적으로 형성되어 오면서 그 의미가 변천해온 과정을 다루지는 못했다. 제도화의 측면에서의 변화가 이러한 사회문화적 측면과 결합하는 양상에 대한 연구는 향후 과제로 남겨둔다. 
장인성, 「냉전과 일본의 자유주의: 마루야마 마사오의 냉전자유주의와 리얼리즘」, 『동북아역사논총』

59호, 동북아역사재단, 2018.

허우성, 『근대일본의 두 얼굴: 니시다철학』, 문학과지성사, 2000.

高山岩男(花澤秀文編), 『超近代の哲学』, 燈影舎, 2002.

高山岩男, 『文化類型学』, 弘文堂, 1939.

高山岩男, 『世界史の哲学』, 岩波書店, 1942.

高山岩男, 『日本の課題と世界史』, 弘文堂, 1943.

高山岩男, 『日本民族の心: 文化類型学的考察』, 玉川大学出版部, 1972.

高山岩男, 『場所的論理と呼応の原理』, 弘文堂, 1951.

高山岩男, 『哲学的人間学』, 岩波書店, 1938.

高坂正顕,『歷史的世界』, 岩波書店, 1937.

鈴木康史, 「明治期日本における「主体」の変容と「身体」のゆくえ」、近代教育フォーラム』第18卷,

2009.

福田恆存, 「絶対者の役割」, 福田恆存全集』第4卷, 文藝春秋社, 1987.

森哲郎, 「解説」, 森哲郎編, 『世界史の理論』, 燈影舎, 2000.

森哲郎編, 『世界史の理論』, 燈影舎, 2000.

西田幾太郎, 『西田幾太郎全集』第12卷, 岩波書店, 1949.

小林敏明, 『〈主体〉のゆくえ: 日本近代思想史への一視角』, 講談社, 2010.

長谷正當,「解説」, 高坂正顕, 『歴史的世界』, 燈影舎, 2002.

前田角藏, 「主体性と他者：終戦直後の文学論争と現在の〈日本〉」, ${ }^{\circledR 日}$ 日本文学』44巻11号, 1995.

花澤秀文, 「解説」, 高山岩男, 『世界史の哲学: 戦後日本思想の原点』, こぶし書房, 2001.

Goto-Johnes, Christopher, "The Kyoto School and the History of Political Philosophy," Christopher

Goto-Jones ed, Re-Politicising the Kyoto School as Philosophy, Routledge, 2008.

\section{'전재민'(戰災民)에서 ‘피폭자'(被爆者)로: 일본 원폭피폭자원호의 제도화와 새로운 자격 의 범주로서 ‘피폭자’의 의미 구성 | 오은정}

권혁태, 「히로시마/나가사키의 기억과 '유일피폭국’의 언설」, 『일본비평』제 1 호, 2009, 60 89쪽. 박경섭, 「조선인원폭피해자와 초국적 시민(권)」, 『현대사회과학연구』 제13권, 2009, 153 166쪽.

被爆者援護法令研究会, 『原爆被爆者関係法令通知集』, 2003.

根本雅也, 『広島の戦後三○年間にみる原爆被害の表象と実践』, 一橋大学社会学研究課修士論文,

2006.

竹峰誠一郎,「被爆者’という言葉がもつ政治性」、立命平和研究』9号, 2008.

広島県原爆被爆者団体協議會, 『核兵器のない明日願をって：広島被団協の歩み』, 2001.

笹本征男, 『米軍占領下の原爆調査: 原爆被害国になった日本』, 新幹社, 1995.

広島市, 『原爆被爆者対策事業概要』, 広島市, 2001.

中島竜美, 「“朝鮮人被爆’の歴史的意味と日本の戦後責任」『在韓被爆者を考える』, 在韓被爆者問題 市民会議編, 凱風社, 1988 .

Lindee, Susan, Suffering made Real: American Science and the Survivors at Hiroshima, Chicago \& London: The University of Chicago Press, 1994.

Todeschini, Maya, "Illegitimate sufferers: A-bomb victims, medical science, and the government", 
Daedalus, Vol. 128, no.2, 1999, pp.67 100.

Yoneyama, Lisa, Hiroshima Traces: Time, Space, and the Dialectics of Memory, University of California Press, 1999.

수폭괴수 고질라의 탄생과 특촬 테크놀로지: 제국과 포스트제국의 단속적 선율 | 이경희 강태웅, 「국가, 전쟁 그리고 ‘일본영화’: 진주만 공습 1주년 기념영화를 중심으로」, 『일본역사연구』, 2007. 6.

이경희, 「특촬물로 본 '일본’과 '세계’의 후지산, 『일본학보』, 2013. 8.

岩崎䄄, 『(日本近現代史)映画史』, 東洋経済新報社, 1961.

瓜生忠夫, 『日本の映画』, 岩波新書, 1956.

加藤典洋、『さようなら, ゴジラたち: 戦後から遠く離れて』, 岩波書店, 2010 ,

「企画だけの面白さ『ゴジラ』(東宝)」,『朝日新聞』, 1954.11.3.

「『ゴジラ』より数段勝る『原始怪獣現わる 米·J·ディーツ, H·チェスター・ブロ, 大映配給』」、読売 新聞』, 1954. 12.17.

竹内博·村田英樹(編), 『ゴジラ 1954』, 実業の日本社, 1999.

田中友幸, 「刊行によせて」,『ゴジラ: 特撮映像の巨星』, 朝日ソノラマ, 田中友幸監·東宝株式会社協 力, 1978. 5. 1 .

「ちょっとスゴイ!? 放射能の怪獣『ゴジラ』(東宝)」、『毎日新聞』, 1954. 11. 4.

鶴見俊輔, 「戦争批判の眼」、映画芸術』, 1957.3.

「みものは特殊撮影だけ: 怪獣映画「ゴジラ」=東宝」、読売新聞』, 1954.11. 3.

[영화]

〈ゴジラ〉 (1954)

〈太本洋の鷲〉 (1953)

〈ハワイ・マレー沖海戦〉 (1942)

The Beast from 20,000 Fathoms (1953)

\section{아베정권 시기의 외교·안보에 대한 여론과 정책 | 경제희}

경제희, 「일본 정치에서의 북한 쟁점-선거 및 내각지지율을 중심으로」, 『통일전략』9(2), 2009, 157 179쪽.

경제희, 「일본 자민당의 집권은 보수적 유권자 결집의 결과인가: 2012 년 중의원선거에서의 일본 유 권자의 이데올로기와 정당 선택」, 『일본연구논총』 $45,2017,91$ 122쪽.

김용복, 「일본 우경화, 한일관계 그리고 동아시아-과거사 갈등과 영토분쟁」, 『경제와 사회』99, 2013, 36 62쪽.

이지원, 「일본의 ‘우경화’: ‘수정주의적 역사인식'과 아베식 '전후체제 탈각의 한계」, 『경제와 사회』 101, 2014, 53 86쪽.

蒲島郁夫·竹中佳彦, 『現代日本人のイデオロギー』, 東京大学出版会, 1996.

蒲島郁夫·竹中佳彦, 『イデオロギー』, 東京大学出版会, 2012.

白崎護,「有権者のイデオロギーにおよぼす政策争点の重要性と政治信頼の影響」『『静岡大学法政 研』20(2), 2015, 39 67驽. 
석이나 작품 유통에 대한 논의에 그치지 않고, 그러한 구체적인 논의에 기초하면서 한국사 전체에 대 해 의견을 나누어 볼 수 있는 드문 기회를 제공한다. 그 뿐 아니라, 논자들이 문학에서 출발하여 사회 사 혹은 정치학까지 언급하니 만큼, 많은 이들이 그 필요성을 역설해온 다학제적 연구가 가능한 논의 의 장이기도 하다. 이에 필자는 국문학계 해당 논쟁들을 비판적으로 검토함을 통해, 조선 후기 국가와 사회, 그리고 그 안을 살아가는 행위자의 이해에 한발자국 다가가고자 한다. 그 과정에서 문학에서 정 치에 이르는 또 다른 경로, 보다 구체적으로는 텍스트의 독해에서 조선 후기의 정치적 동학의 이해에 이르는 대안적인 경로를 제안하고자 한다.

주제어: 이언진, 한글 소설, 조선 후기, 국가, 사회

\section{연구논단}

\section{세계사와 포월적 주체: 고야마 이와오의 역사철학과 근대비판 | 장인성}

투고일자: 2018.6.12 | 심사완료일자: 2018.7.7 | 게재확정일자: 2018.7.13

이 글에서는 고야마 이와오(高山岩男, 1905 1993)의 역사철학과 주체 문제를 살펴봄으로써 1930년 대, 1940년대 일본에서 제국과 전쟁 상황의 현실에 대면했던 교토철학의 사상적 영위 내용과 특질을 밝히고 있다. 교토학파의 역사철학은 일본근대철학의 자연적 추세(시간성) 위에 세계사의 혁명적 재 구성(공간성)이 부과된 형태로 전개되었다. 교토학파의 세계사철학에서 자연과 작위를 연결하고 시 간과 공간을 결합시킨 계기는 전쟁이었다. 고야마는 유럽세계를 하나의 근대적 세계로 상대화하는 한 편, 유럽 중심의 국제질서를 수정하고 일본의 역사적 세계가 포함된, 일본이 주도하는 세계사적 세계 를 재구성하고자 했다. 또한 역사적 세계와 세계사적 세계를 지탱하는 서양문화와 동양문화의 관계를 재설정하고자 했다. 고야마는 유럽의 근대와 근대국가를 부정했지만 근대성 전체를 거부하지는 않았 다. 개체적 책임주체와 자주적 정신을 중시하는 한편, 일본적 가치가 투사된 동양정신으로써 동서양 의 포섭적 초월을 추구하였다. "이성을 포월하는 인간의 철학"을 지향하였다.

주제어: 고야마 이와오, 교토철학, 주체/주체성, 유럽근대 비판, '세계사적 세계'/역사적 세계', ‘포 월', 제국과 전쟁

\section{‘전재민'(戰災民)에서 ‘피폭자'(被爆者)로: 일본 원폭피폭자원호의 제도화와 새로운 자격 의 범주로서 ‘피폭자'의 의미 구성 | 오은정}

투고일자: 2018.6.20 | 심사완료일자: 2018.6.27 | 게재확정일자: 2018. 7.3

본고는 패전 직후 일반의 전재민(戰災民)과 구분되지 않았던 히로시마와 나가사키의 원폭피해자들이 원폭피해자구호정책의 제도화에 따라 '피폭자(被爆者)', 즉 '히바쿠샤'로 규정되어온 역사적 맥락을 살펴보았다. 패전 직후 히로시마와 나가사키에 투하된 원폭에도 '살아남은 사람들' 즉 '원폭생존자'는 구호의 측면에서는 '일반의 전재민'들과 동일한 범주에 놓여 있었다. 그러나 샌프란시스코 강화조약 과 비키니피재 이후 일본의 원폭피해자구호가 빠르게 법적 - 행정적 제도화 과정에 들어섰고, 이 과정 에서 기존의 '원폭장해자', '원폭환자' 등의 용어가 아닌 '원폭피폭자'라는 행정관료제적 명칭이 중요 하게 자리잡게 된다. 그리고 그 실행과정에서는 일본국의 영토, 그리고 원자폭탄의 피해가 전쟁으로 인한 '일반의 피해’와 구분되는 ‘특수한 피해’인 경우에 한정되어야 한다는 수인론(受忍論)과 균형론 (均衡論)이 중요하게 내세워졌다. 이렇게 커다란 두 축의 움직임은 일본에서 '피폭자'가 갖는 정치사 회적 의미와 법적 규정이 과거 일본국이 수행한 전쟁이나 식민지배에 대한 책임이 아니라 그 피해를 
초래한 원인도 주체도 명시하지 않은 오직 원자폭탄에 의한 생물학적 손상에 대한 보상에 한정되는 것, 즉 제국 일본이 수행한 전쟁의 책임이 소거(消去)되는 과정으로 틀 지워짐을 의미한다.

주제어: 피폭자, 전재민, 제국 일본, 전쟁책임, 수인론, 균형론

수폭괴수 고질라의 탄생과 특촬 테크놀로지: 제국과 포스트제국의 단속적 선율 | 이경희 투고일자: 2018.6.26 | 심사완료일자: 2018.7.6 | 게재확정일자: 2018.7.13

이 논문에서는 특촬영화 〈고질라〉(1954)의 탄생 서막을 재조명했다. 이로써 제국 일본의 문화권력을 지탱했던 테크놀로지가 전후 일본의 '수폭괴수’와 결합하며 포스트제국으로 이행한 단속적 선율과 그 문화적 함의를 규명했다.

특수촬영기술(SFX)은 전쟁·프로파간다 영화를 보조하며 제국 일본에 ‘혁혁한' 공을 세웠고, 아 시아· 태평양전쟁은 특촬 테크놀로지 향상에 다대한 영향을 미쳤다. 특촬(SF)의 전후 과제는 그 핵심 적 장면들(폭격, 격파, 침몰, 파괴 등) 속에 전후의 새로운 이념을 녹여냄으로써 전전과의 단절을 체 화하는 것이었다. 그 가능성은 비키니환초의 수폭실험과 후쿠류마루사건을 모티프로 한 '수폭괴수' 와 조우하면서 열렸다. 특촬과 '수폭괴수’의 결합에는 전후 세계의 역사적 사건과 사고와 우연들이 얽 히면서 〈고질라〉는 제국의 이데올로기나 이원론적 대립 구도 너머로 다음과 같은 불확정적 상징성을 획득했다.

첫째, 고질라는 수폭실험의 피해자면서 난폭한 파괴자, 정당한 고발자면서 잔혹한 가해자, 소외 된 외부자면서 잠재된 내재자라는 복합적 양가성- 다의성을 띠게 됐다. 둘째, '수폭괴수'와 결합한 특 촬 테크놀로지는 문명비판(공포) vs 오락(애교)을 횡단하며 제국 일본의 문화권력에서 포스트제국 일 본의 문화 콘텐츠로 거듭났다. 셋째, 미국영화의 '재탕'이면서 일본영화로서는 최초로 브로드웨이와 세계시장을 제패함으로써, 원작(전승국) vs 모작(패전국)의 우열론적 대립구도를 해체했다. 그리고 이는 제국의 문화권력과의 유착 관계 속에서 영화의 보조적 위치 머물던 전전의 특촬 테크놀로지를 영화의 중심에 두고자 했던 제작 의도의 또 다른 결과였다.

주제어: 고질라(1954), 특촬 테크놀로지, 수폭괴수, 양가성, 제국과 포스트제국

\section{아베정권 시기의 외교·안보에 대한 여론과 정책 | 경제희}

투고일자: 2018.7.4 | 심사완료일자: 2018.7.9 | 게재확정일자: 2018.7.14

본 연구에서는 여론의 추이를 통해 일본 시민의 외교 · 안보의식과 아베정권의 외교 · 안보정책 간의 관계를 살펴보았다. 일본의 정치가와 시민을 구분하고 역사 및 영토 문제와 외교· 안보 이슈를 분리 하여 일본 시민의 외교 - 안보의식에 초점을 맞춰 분석을 실시하였다. 또한 다양한 여론 조사에 따라 그 결과가 다를 수 있기 때문에 국공립기관의 여론조사 결과와 민간기관의 여론조사 결과를 구별하 여 분석하였다. 구체적으로는 미국, 중국, 한국을 중심으로 한 국가 간 관계, 안전보장 및 평화, 헌법개 정 - 자위대 · 집단적 자위권 행사와 관련하여 제 2 차 아베내각이 출범한 2012년 말부터 2017년 말까 지 조사된 다양한 여론조사 결과의 추이를 살펴보았다. 결과적으로 중국 및 한국과의 관계를 비롯하 여 여러 원인으로 인한 군사적 충돌에 대한 우려는 높지만 이에 대한 해결 방안으로 무력을 행사하는 방향의 정책은 선호하지 않는 시민의 비율이 높은 것으로 나타났다. 또한 제 2 차 아베내각이 들어선 이후 그러한 의식의 경향이 조금씩 높아지는 경향을 보여 아베정권의 외교 · 안보정책은 다수의 일본 시민의 외교 · 안보 의식과는 다른 방향으로 움직이는 것으로 보여진다.

주제어: 일본 시민, 여론, 외교 · 안보, 안전보장, 평화, 헌법개정, 자위대, 집단적 자위권, 아베정권 
Eon Jin Yi's poems and the extent to which Korean vernacular literature had been circulated in late Chosŏn Korea. The controversy reigns as to whether Yi was radical enough and whether there was nationwide circulation of Korean novels. In this article, I do not seek to abjudicate these debates. Rather, I explore the ways in which one can reconsider state-society relation and various agents negotiated their ways through appropriation of existing social norms and values.

- Keywords: Eon Jin Yi, Korean literature, Chosŏn, the State, Society

\section{ARTICLES}

\section{Inclusive-Transcendental Subject in World History: Koyama Iwao's Philosophy of History and His Criticism of Modernity | JANG In-Sung}

By focusing on the philosophy of history and the idea of subjectivity of Koyama Iwao(1905 1993), the article explains the contents and traits of the Kyoto School's philosophy conducted in the context of empire and war during the 1930s and the 1940s. Kyoto School intellectuals' idea of historical philosophy basically was to structurally construct the world-historical world on the basis of the historical unfolding of Japanese modern philosophy. The momentum was Japanese imperialist war that had combined the natural/temporal development with the artificial/spatial transformation in the Kyoto thinkers' philosophy of history.

While relativizing the European world as a modern world, Koyama endeavored to revise the Europe-centered international order and newly construct a Japan-led, world-historical world that contains Japanese historical world as a key component. He also imagined the conflation of Western culture and Eastern culture in which the historical world and the world-historical world had been based on. Koyama thought European modernity and modern nation-state were no longer valid even though he did not completely deny modernity itself. While respecting individual responsibility and self-reliance, he pursued the transcendental overcoming of both the East and the West by emphasizing the Oriental spirit based on Japanese values. Koyama aimed for the establishment of "human philosophy inclusively transcending human reason."

- Keywords: Koyama Iwao, the Kyoto School, Subject/Subjectivity, Criticism of European modernity, 'World historical world'/'Historical world', 'Inclusive-transcendence', Empire and war.

\section{From "War Victim" to "Hibakusha": Shaping the Conceptual Boundary of Hibakusha and Its Meaning | OH Eunjeong}

The purpose of this article is to identify the historical relations and interplays of science, politics, and bureaucracy that are key factors in forming a legal boundary of Hibakusha in Japan. Based on various scientific and medical researches, the boundary was bureaucratically determined by political justification for unbalanced post-war compensation and strong administrative rules. The historical process that constitutes the conceptual boundary of Hibakusha shapes structures of the legal and bureaucratic boundaries of Hibakusha specifically, which involves a territorial boundary and connotes symbolic and 
political meaning, erasing the past Japan Empire's war responsibility.

- Keywords: Hibakusha, War victim, Japan Empire's war responsibility

\section{The Birth of Godzilla, the Hydrogen Bomb Monster, and SFX Technology: The Intermittent Melody of Empire and Post-Empire | LEE Kyunghee}

This paper sheds new light on the prologue to the birth of SFX film, Godzilla(1954), revealing the (dis) continuity along which the technology supporting the cultural power of imperial Japan was transferred to the post-empire era by combining it with the "hydrogen bomb monster" in the post-war Japan.

SFX technology made a significant contribution to imperial Japan by supporting war/propaganda films, and the Asia-Pacific war played a key role in enhancing SFX technology to an advanced level. The major challenge of the post-war SF industry was to embody the disconnection from the preimperal past by embedding new post-war ideologies in key scenes of films (bombing, defeat, sinking, destruction, etc.). Underlying the combination of SF technology and the "hydrogen bomb monster" were many intertwined historic events, incidents, and coincidences of the post-war world. They generated contradicting or ambiguous factors, enabling Godzilla to obtain indeterminate symbolism beyond the binary opposition of dualism as follows:

First, Godzilla expressed complex ambivalence by being both a hydrogen bomb test victim and a violent destroyer, a legitimate accuser and a cruel assailant. Second, SFX technology, combined with the "hydrogen bomb monster," crossed criticism of civilization with entertainment and reformed the culture of post-war Japan from the cultural establishment of imperial Japan. Third, by being the first Japanese film that conquered Broadway and the global market - although it was a "imitation" of an American film - Godzilla unraveled the structure of competition based on superiority between the original (the victor nation) and the imitation (the defeated nation). This was another consequence of the producer's intent to place SFX technology on the center stage of film, which had been located in a subsidiary position under the cozy relationship with the empire's cultural power.

- Keywords: Godzilla(1954), SFX technology, hydrogen bomb monster, ambiguous factors, empire and post-empire

\section{The Japanese Public Opinion and the Foreign and Security Policies under the Abe Administration | KYUNG Jeihee}

The study analyzed the relationship between the Japanese public opinion and the foreign and security policies under the Abe administration. The analysis focused on the Japanese citizen's consciousness about the Japanese foreign and security policies, first, by separating them from the Japanese politicians and, second, by separating historical and territorial issues from foreign and security issues. Since various public opinion polls show different conclusions, the analysis distinguishes polls conducted by national and private institutions. Specifically, public opinions on three issues -1) foreign relations centered on the United States, China and Korea, 2) security and peace, 3) constitutional revision, the Self-Defense Forces and the right of collective self-defense - carried out during the second Abe Cabinet which was launched from the late 2012 to 2017 were analyzed. As a result, it turns out that concerns were 